\title{
UCRL-TR-216745
}

LAWRENCE LIVERMORE

\section{Radionuclide Reaction Chemistry as a Function of Temperature at the Cheshire Site}

Elizabeth A. Burton, Carol J. Bruton, Mackenzie R. Johnson, Joseph Rard and Mavrik Zavarin

September 6, 2005 


\section{Disclaimer}

This document was prepared as an account of work sponsored by an agency of the United States Government. Neither the United States Government nor the University of California nor any of their employees, makes any warranty, express or implied, or assumes any legal liability or responsibility for the accuracy, completeness, or usefulness of any information, apparatus, product, or process disclosed, or represents that its use would not infringe privately owned rights.

Reference herein to any specific commercial product, process, or service by trade name, trademark, manufacturer, or otherwise, does not necessarily constitute or imply its endorsement, recommendation, or favoring by the United States Government or the University of California.

The views and opinions of authors expressed herein do not necessarily state or reflect those of the United States Government or the University of California, and shall not be used for advertising or product endorsement purposes.

\section{Auspices Statement}

This work was performed under the auspices of the U.S. Department of Energy by University of California, Lawrence Livermore National Laboratory under Contract W-7405-Eng-48.

This report has been reproduced directly from the best available copy.

Available to DOE and DOE contractors from the Office of Scientific and Technical Information

P.O. Box 62, Oak Ridge, TN 37831

Prices available from (423) 576-8401

http://apollo.osti.gov/bridge

Available to the public from the National Technical Information Service

U.S. Department of Commerce 5285 Port Royal Rd, Springfield, VA 22161 http://www.ntis.gov/

\section{OR}

Lawrence Livermore National Laboratory Technical Information Department's Digital Library http://www.llnl.gov/library/ 


\title{
Radionuclide Reaction Chemistry as a Function of Temperature at the Cheshire Site
}

Elizabeth A. Burton, Carol J. Bruton, Mackenzie R. Johnson, Joseph Rard and Mavrik Zavarin

Environmental Science Division

Energy and Environment Directorate

Lawrence Livermore National Laboratory

Livermore, California

\author{
Prepared for the Underground Test Area Project \\ U. S. Department of Energy \\ National Nuclear Security Administration \\ Nevada Site Office
}

Final Report

September 6, 2005 


\section{TABLE OF CONTENTS}

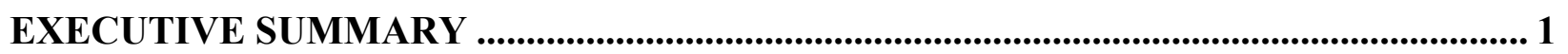

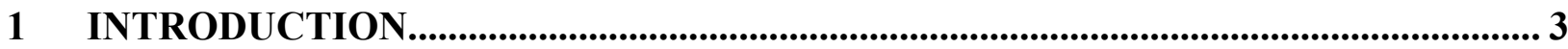

2 SPECIATION DATA AVAILABLE IN THE LITERATURE ........................................ 5

3 SPECIATION ALGORITHMS FOR DATA EXTRAPOLATION ................................5

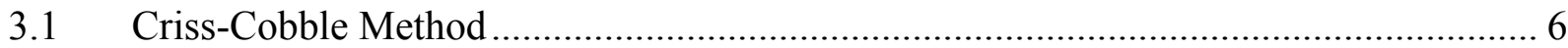

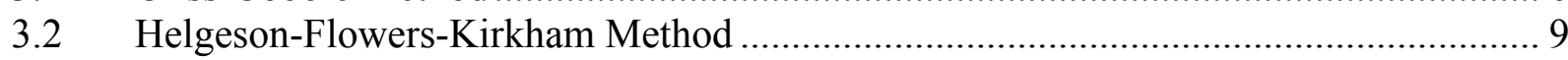

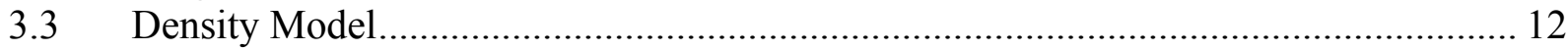

$3.4 \quad$ Isoelectric or Isocoulombic Reaction Extrapolation.................................................... 13

4 ANALOG SPECIES ........................................................................................................ 14

5 SUMMARY OF RADIONUCLIDE SPECIATION WITH TEMPERATURE BASED

ON AVAILABLE DATA .................................................................................................... 14

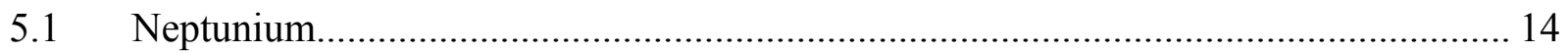

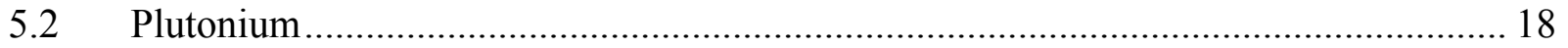

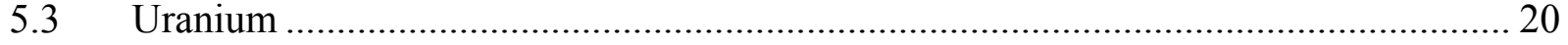

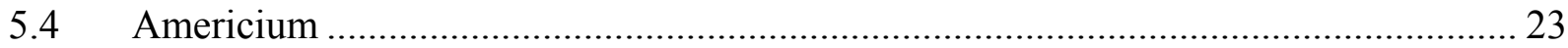

6 IMPLICATIONS FOR MOBILITY OF RADIONUCLIDES ....................................... 24

7 CONCLUSIONS AND RECOMMENDATIONS.............................................................. 26

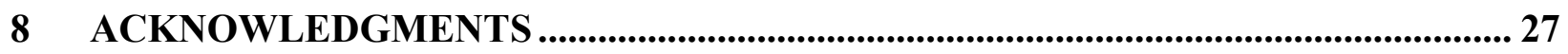

9 REFERENCES.............................................................................................................. 28

APPENDIX : SELECTED REFERENCES FROM LITERATURE SEARCH..................... 31 


\section{LIST OF TABLES}

Table 1: Ambient groundwater chemistry used in Cheshire HST simulations (from Table 6.10, Pawloski et al., 2001)...............................................................................4

Table 2. Aqueous complexation reactions included in Cheshire HST simulations (from Table J.3 of Pawloski et al., 2001)..................................................................5

Table 3. Parameter values for calculating average heat capacities in cal $/ \mathrm{mol} / \mathrm{K}$ (Criss

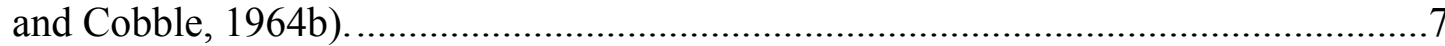

Table 4. Estimated entropy parameters above $150^{\circ} \mathrm{C}$ by Criss-Cobble method (Criss and Cobble, 1964b).

Table 5: Criss-Cobble heat capacity parameters to calculate absolute heat capacities at $25^{\circ} \mathrm{C}$ in units of $\mathrm{cal} / \mathrm{mol} / \mathrm{K}$.

Table 6. Coefficients for Equation 3-5 for heat capacity estimates from entropy at $25^{\circ} \mathrm{C}$ using the methods of Shock and Helgeson (1988), Shock et al (1997a, 1997b) Units of $\mathrm{cal} / \mathrm{mol} / \mathrm{K}$.

Table 7. Available thermodynamic data and calculated heat capacities for simple cations using the Shock-Helgeson family of coefficients shown in Table 4.

The +/- columns list uncertainties in thermodynamic values. The number of significant figures reported is carried over from each reference. The heat capacities were calculated using the following equations: $\mathrm{Am}^{2+}$ : divalent transition metal cations; $\mathrm{Am}^{3+}$ : LREE trivalent; $\mathrm{Pu}^{3+}, \mathrm{Np}^{3+}, \mathrm{U}^{3+}$ : HREE trivalent; $\mathrm{Am}^{4+}, \mathrm{U}^{4+}, \mathrm{Pu}^{4+}, \mathrm{Np}^{4+}$ : tetravalent cations.

Table 8: Thermodynamic data for species and isocoulombic reactions involving $\mathrm{Np}$.

Data are from Guillaumont et al. (2003) except for heat capacity of $\mathrm{Np}^{4+}$ which is from Lemire and Tremaine (1980). The number of significant figures reported is carried over from each reference.

Table 9: Calculated log K values using Equations 3-12 and 3-13 above. See text for discussion. Data used in calculations are shown in Table $8 .^{1}$

Table 10: Thermodynamic data for species and isocoulombic reactions involving $\mathrm{Pu}$.

Data are from Guillaumont, et al. (2003) except for enthalpy data for $\mathrm{Pu}(\mathrm{OH})_{4(\mathrm{aq})}$ and $\mathrm{PuO}_{2}(\mathrm{OH})_{(\mathrm{aq})}$ which are from Lemire et al. (2001). The number of significant figures reported is carried over from each reference.

Table 11: Calculated log K values using Equations 3-12 above. See text for discussion. Data used in calculations are shown in Table $10 .^{1}$

Table 12: Thermodynamic data for species and isocoulombic reactions involving $U$.

Data are from Guillaumont, et al. (2003). The number of significant figures reported is carried over from each reference.

Table 13: Calculated $\log \mathrm{K}$ values using Equations 3-12 and 3-13 above. See text for discussion. Data used in calculations are shown in Table 12. ${ }^{1}$

Table 14: Thermodynamic data for Am species. Data are from Guillaumont, et al. (2003) with the exception of the enthalpy value for the reaction involving $\mathrm{AmCO}_{3}{ }^{+}$, which was derived from Wruck et al. (1999). The number of significant figures reported is carried over from each reference. 


\section{LIST OF FIGURES}

Figure 1: Comparison of Criss-Cobble(C-C) and Shock-Helgeson (S-H) calculated $\mathrm{Cp}$ trends for different groups of simple cations (labels denote groups of 1+, $2+, 3+$, and $4+$ cations, above) at $25^{\circ} \mathrm{C}$, with heat capacity data. ShockHelgeson algorithms come from several references as described in text. The labels HREE and LREE refer respectively to heavy and light rare earth elements.

Figure 2: Calculations of heat capacity values using Shock-Helgeson algorithms for $\mathrm{Am}, \mathrm{Pu}$, and $\mathrm{U}$ using available enthalpy data. Calculated values shown as white circles. Labels denote groups of $2+, 3+$, and $4+$ cations, heavy (HREE) and light (LREE) rare earth elements. For Pu and U, there are some tabulated heat capacity data also. These data are plotted for comparison. The HREE algorithm was used for $3+$ ions except for Am which is considered to have analogs with LREE, $\mathrm{Ce}$ and $\mathrm{Eu}$.

Figure 3: Calculation of heat capacity changes with temperature using the density model of Mesmer et al. (1988). The contours are labeled with values of heat capacities at $25^{\circ} \mathrm{C}$.

Figure 4: Plot of the temperature dependence of $\log \mathrm{K}$ for the two Np speciation reactions included in the Cheshire HST model. For the $\mathrm{Np}^{4+}$ to $\mathrm{NpO}_{2}{ }^{+}$ reaction, both Eqs. 3-12 (solid line) and 3-13 (dashed line) were used. For the $\mathrm{NpO}_{2}{ }^{+}$to $\mathrm{NpO}_{2} \mathrm{OH}^{\mathrm{o}}$ reaction, Eq. 3-12 was used.

Figure 5: Plot of the temperature dependence of $\log \mathrm{K}$ for two Pu speciation reactions

Figure 6: Plot of the temperature dependence of $\log \mathrm{K}$ for selected $\mathrm{U}$ speciation reactions. 


\section{EXECUTIVE SUMMARY}

The goals of this task were to evaluate the availability of published temperature-dependent thermodynamic data for radionuclides and sorbing minerals and to evaluate the applicability of published estimation methods for temperature-dependent aqueous complexation, radionuclide mineral precipitation, and sorption. This task fills a gap in the hydrologic source term (HST) modeling approach, which, with few exceptions ${ }^{1}$, has neglected the effects of temperature on radionuclide aqueous complexation, using $25^{\circ} \mathrm{C}$ complexation data for all temperatures without evaluating the consequences of this assumption. In this task, we have compiled thermodynamic data available in the literature and evaluated the options and benefits of applying temperaturedependent radionuclide speciation to future HST modeling. We use the recent experience of HST modeling at Cheshire (Pawloski et al., 2001) to focus our evaluation.

Our literature search revealed that few thermodynamic data or extrapolation methods could be used to define the temperature-dependent speciation of key HST radionuclides $\mathrm{Np}, \mathrm{Pu}, \mathrm{Am}$, and $\mathrm{U}$, particularly for the higher valence-state (e.g., 5+ and $6+$ ), the oxidation states most pertinent to NTS groundwater conditions at Cheshire. This suggests that using $25^{\circ} \mathrm{C}$ data for all temperatures may be the best modeling approach currently available. We tested established estimation techniques such as the Criss-Cobble method and other correlation algorithms to calculate thermodynamic parameters needed to extrapolate aqueous complexation data to higher temperatures. For some reactions, the isocoulombic method does allow calculation of free energy data and equilibrium values at higher temperatures. Limitations in algorithms and input data for pentavalent and hexavalent cations prevent extending temperature ranges for reactions involving radionuclides in these oxidation states and their complexes. In addition, for many of the radionuclides of interest, carbonate complexes appear to be the dominant complexes formed in NTS groundwaters, and data for these types of complexes are lacking for radionuclides as well as analog species.

For the few species where enough data are available, the effect of temperature on radionuclide aqueous complexation has been calculated. These calculations allow partial estimation of the potential error that may be involved in ignoring speciation changes as a function of temperature, as was done in the Cheshire HST model (Pawloski et al., 2001). In some cases, differences between the most recent $25^{\circ} \mathrm{C}$ data available in the literature and data used in Pawloski et al. (2001) were more significant than calculated speciation changes as a function of temperature. To incorporate radionuclide speciation as a function of temperature, a robust set of temperaturedependent reaction constants is necessary. Based on our literature search and the few reactions that could be extrapolated to higher temperatures, the change in dominant complexes with temperature cannot be adequately addressed at this time. However, the effect of temperature on speciation can be qualitatively examined.

\footnotetext{
${ }^{1}$ Wolfsberg, et al. (2002) included temperature effects for a limited set of Pu complexes in their THC source-term model for the TYBO/BEHNHAM tests, using data from the EQ3/6 database (Wolery, 1983).
} 
In general, the $\log \mathrm{K}$ values for radionuclide complexation reactions considered here increase with increasing temperature, suggesting that increasing temperature may enhance radionuclide aqueous complexation. However, complexation reactions often involve $\mathrm{H}^{+}$and reactant species such as carbonate which exhibit their own temperature-dependent speciation. Thus, any change in the value of a radionuclide complexation $\log \mathrm{K}$ may be offset or enhanced by temperature effects on $\mathrm{pH}$ and carbonate speciation. In addition, sorption processes that involve surface complexation change with increasing temperature, and these reactions may enhance or negate the mobility effects of any increase in aqueous complexation with temperature. While increasing temperature may increase complexation, it also may reduce or increase ligand concentrations through shifts in speciation. Similarly, higher temperatures may favor or reduce sorption and/or co-precipitation in mineral phases. Consequently, the net effect on radionuclide mobility of increasing temperature depends on the effects of temperature on a number of geochemical processes. Thus, it is even difficult to make qualitative assumptions about the direction much less the magnitude of temperature effects on radionuclide mobility. Until sufficient data become available in the literature to precisely capture the effects of temperature on radionuclide complexation, it appears unwarranted to invest in complex estimation techniques based on extrapolations from available data.

In the context of field-scale transport modeling, it is also apparent that using $25^{\circ} \mathrm{C}$ complexation data for all temperatures is currently the best transport modeling alternative for the Cheshire HST model. The model error associated with using $25^{\circ} \mathrm{C}$ complexation constants is small relative to many other assumptions made in the modeling. High temperatures are located primarily in the glass zone of underground nuclear tests. The volume of the glass zone is very small when compared to the region encompassed by the 1000-year transport path of most radionuclides. Furthermore, high temperatures in the glass zone are transient and are not likely to be present over the entire 1000-year timeframe of HST. Thus, spatially and temporally within the models, the overall effect of neglecting complexation temperature dependence on the results of long-term and long-distance reactive transport modeling will be small. However, this is not to imply that temperature gradients are unimportant over the far field region or over long-time frames. Temperature gradients will control radionuclide transport through many physical as well as chemical effects, including thermal buoyancy effects, convection, solubility and species concentration gradients, all of which will impact the thermodynamic drive and kinetics of complex formation, sorption, colloidal transport, ion exchange and many other reactions. 


\section{INTRODUCTION}

Underground nuclear tests result in elevated near-field temperatures that can be sustained for many years (Pawloski et al., 2001; Carle et al., 2003). The most active period of fluid transport and reaction chemistry also occurs at this time (tens to hundreds of years after a test). Testrelated heat drives thermally driven flow and drastically increases mineral dissolution/precipitation rates. The test-related heat can impact radionuclide migration through changes in aqueous speciation, surface complexation/ion exchange, and mineral precipitation/dissolution rates. Increased temperatures may favor or limit radionuclide transport through changes in aqueous speciation and sorption. Similarly, solubility of radionuclide precipitates may be enhanced or reduced, which would also affect radionuclide migration. Recent Cheshire hydrologic source term (HST) modeling focused on the impact of temperature on glass dissolution rates (Pawloski et al., 2001). However, the temperature dependence of aqueous speciation and sorption was not included: $\log \mathrm{K}$ values at $25^{\circ} \mathrm{C}$ were applied at all temperatures. The focus of this report is to evaluate the speciation data available in the literature and assess the potential impact of neglecting test-related high temperatures on radionuclide speciation (and resulting migration) in the near field, with particular emphasis on recent Cheshire HST calculations.

In recent Cheshire HST simulations (Pawloski et al., 2001), an ambient groundwater chemistry was determined based on groundwater compositional data from Areas 19 and 20, Pahute Mesa, Nevada Test Site (NTS), and assumptions that groundwater would be in mineral-fluid equilibrium with calcite, hematite and Ca-montmorillonite (Table 1). From these data and considerations about the stability and dominance of various aqueous complexes under the Eh and $\mathrm{pH}$ conditions of the groundwater, a set of radionuclide aqueous complexation reactions was determined (Table 2). The dominant complexes are hydroxides and carbonates. Due to data availability and other constraints at the time of that study, the $\log \mathrm{K}$ values used for the aqueous complexation reactions were $25^{\circ} \mathrm{C}$ data regardless of the temperature in the HST simulations.

Since the Cheshire HST model was completed, the NEA thermodynamic database (NEA-TDB) has been updated (http://www.nea.fr/html/dbtdb/). Also, algorithms for extending thermodynamic data to higher temperatures and pressures have become more accepted as data accumulates for testing their validity on various classes of ions. The goal of this study was to examine how the assumption of isothermal $\log \mathrm{K}$ values may affect predicted radionuclide mobility in the near field and evaluate whether sufficient temperature-dependent radionuclide speciation data are available to incorporate into future HST models. 
Table 1: Ambient groundwater chemistry used in Cheshire HST simulations (from Table 6.10, Pawloski et al., 2001).

\begin{tabular}{|l|l|l|}
\hline \multicolumn{1}{|c|}{ Component } & Concentration (mg/kg) & \multicolumn{1}{c|}{ Concentration (mol/L) } \\
\hline $\mathrm{SiO}_{2}(\mathrm{aq})$ & 56 & $9.4 \times 10^{-4}$ \\
\hline $\mathrm{Na}$ & 65 & $2.83 \times 10^{-3}$ \\
\hline $\mathrm{HCO}_{3}{ }^{1}$ & 107 & $1.78 \times 10^{-3}$ \\
\hline $\mathrm{Al}^{2}$ & $4.9 \times 10^{-5}$ & $1.8 \times 10^{-9}$ \\
\hline $\mathrm{Ca}^{3}$ & 10.4 & $2.6 \times 10^{-4}$ \\
\hline $\mathrm{K}$ & 3.4 & $8.7 \times 10^{-5}$ \\
\hline $\mathrm{Mg}$ & 0.5 & $2.06 \times 10^{-5}$ \\
\hline $\mathrm{Cl}$ & 12 & $3.39 \times 10^{-4}$ \\
\hline $\mathrm{Fe}^{4}$ & $1.6 \times 10^{-7}$ & $2.93 \times 10^{-12}$ \\
\hline $\mathrm{SO}_{4}$ & 35 & $3.64 \times 10^{-4}$ \\
\hline $\mathrm{O}_{2}(\mathrm{~g})$ & $10^{-7}$ bars & $10^{-7}$ bars \\
\hline $\mathrm{pH}^{5}$ & 8.2 & 8.2 \\
\hline
\end{tabular}

${ }^{1}$ Total carbonate as $\mathrm{HCO} 3$.

${ }^{2}$ Set by assuming equilibrium with Ca-montmorillonite.

${ }^{3}$ Set by assuming equilibrium with calcite.

${ }_{5}^{4}$ Set by assuming equilibrium with hematite.

${ }^{5} \mathrm{~A} \mathrm{pH}$ of 8.2 at $35^{\circ} \mathrm{C}$ was calculated from the average $\mathrm{pH}$ of 8.3 at $25^{\circ} \mathrm{C}$ by assuming that the total carbonate concentration does not vary from 25 to $35^{\circ} \mathrm{C}$. 
Table 2. Aqueous complexation reactions included in Cheshire HST simulations (from Table J.3 of Pawloski et al., 2001).

\begin{tabular}{|c|c|}
\hline Complexation reaction & $\begin{array}{c}\log K @ 9 \\
\quad 25^{\circ} \mathrm{C} \\
\end{array}$ \\
\hline $\mathrm{Np}^{4+}+0.25 \mathrm{O}_{2}(\mathrm{~g})+1.5 \mathrm{H}_{2} \mathrm{O}=\mathrm{NpO}_{2}^{+}+3 \mathrm{H}^{+}$ & 9.9 \\
\hline $\mathrm{NpO}_{2}^{+}+\mathrm{HCO}_{3}^{-}=\mathrm{NpO}_{2} \mathrm{CO}_{3}^{-}+\mathrm{H}^{+}$ & 5.7 \\
\hline $\mathrm{NpO}_{2}^{+}+\mathrm{H}_{2} \mathrm{O}=\mathrm{NpO}_{2} \mathrm{OH}^{0}+\mathrm{H}^{+}$ & 8.9 \\
\hline $\mathrm{Np}^{4+}+4 \mathrm{H}_{2} \mathrm{O}=\mathrm{Np}(\mathrm{OH})_{4}{ }^{0}+4 \mathrm{H}^{+}$ & 9.6 \\
\hline $\mathrm{Am}^{3+}+2 \mathrm{HCO}_{3}^{-}=\mathrm{Am}\left(\mathrm{CO}_{3}\right)_{2}^{-}+2 \mathrm{H}^{+}$ & 8.4 \\
\hline $\mathrm{Am}^{3+}+2 \mathrm{H}_{2} \mathrm{O}=\mathrm{Am}(\mathrm{OH})_{2}^{+}+2 \mathrm{H}^{+}$ & 14.1 \\
\hline $\mathrm{Am}^{3+}+\mathrm{HCO}_{3}^{-}=\mathrm{AmCO}_{3}^{+}+\mathrm{H}^{+}$ & 2.5 \\
\hline $\mathrm{Am}^{3+}+2 \mathrm{H}_{2} \mathrm{O}=\mathrm{AmOH}^{2+}+\mathrm{H}^{+}$ & 6.4 \\
\hline $\mathrm{Eu}^{3+}+2 \mathrm{HCO}_{3}^{-}=\mathrm{Eu}\left(\mathrm{CO}_{3}\right)_{2}^{-}+2 \mathrm{H}^{+}$ & 7.7 \\
\hline $\mathrm{Eu}^{3+}+2 \mathrm{H}_{2} \mathrm{O}=\mathrm{Eu}(\mathrm{OH})_{2}^{+}+2 \mathrm{H}^{+}$ & 14.9 \\
\hline $\mathrm{Eu}^{3+}+\mathrm{HCO}_{3}{ }^{-}=\mathrm{EuCO}_{3}^{+}+\mathrm{H}^{+}$ & 2.4 \\
\hline $\mathrm{Sm}^{3+}+2 \mathrm{HCO}_{3}^{-}=\mathrm{Sm}\left(\mathrm{CO}_{3}\right)_{2}^{-}+2 \mathrm{H}^{+}$ & 7.9 \\
\hline $\mathrm{Sm}^{3+}+\mathrm{HCO}_{3}^{-}=\mathrm{SmCO}_{3}^{+}+\mathrm{H}^{+}$ & 2.5 \\
\hline $\mathrm{UO}_{2}{ }^{2+}+2 \mathrm{HCO}_{3}{ }^{-}=\mathrm{UO}_{2}\left(\mathrm{CO}_{3}\right)_{2}{ }^{2-}+2 \mathrm{H}^{+}$ & 3.8 \\
\hline $\mathrm{UO}_{2}{ }^{2+}+3 \mathrm{HCO}_{3}{ }^{-}=\mathrm{UO}_{2}\left(\mathrm{CO}_{3}\right)_{3}{ }^{4-}+3 \mathrm{H}^{+}$ & 9.4 \\
\hline $\mathrm{UO}_{2}{ }^{2+}+\mathrm{H}_{2} \mathrm{O}=\mathrm{UO}_{3}{ }^{0}+2 \mathrm{H}^{+}$ & 10.3 \\
\hline $\mathrm{UO}_{2}{ }^{2+}+2 \mathrm{H}^{+=} \mathrm{U}^{4+}+0.5 \mathrm{O}_{2}(\mathrm{~g})+\mathrm{H}_{2} \mathrm{O}$ & 32.5 \\
\hline $\mathrm{U}^{4+}+2 \mathrm{H}_{2} \mathrm{O}=\mathrm{UO}_{2}^{0}+4 \mathrm{H}^{+}$ & 4.6 \\
\hline $\mathrm{Pu}^{4+}+2 \mathrm{HCO}_{3}^{-}+2 \mathrm{H}_{2} \mathrm{O}=\mathrm{Pu}(\mathrm{OH})_{2}\left(\mathrm{CO}_{3}\right)_{2}{ }^{2-}+4 \mathrm{H}^{+}$ & 2.8 \\
\hline
\end{tabular}

\section{SPECIATION DATA AVAILABLE IN THE LITERATURE}

The Appendix lists all pertinent references explored in our search of recent literature. It provides a comprehensive list of recent and some historical publications regarding the aqueous speciation of radionuclides. A subset of these references was used to summarize the state of temperaturedependent radionuclide speciation and extrapolation methods, as described below.

\section{SPECIATION ALGORITHMS FOR DATA EXTRAPOLATION}

Experimental data needed to calculate the temperature dependence of equilibrium constants, Gibbs free energies, enthalpies, or entropies are unavailable for many of the radionuclide species of interest. Various procedures to estimate the temperature dependence of these thermodynamic parameters have been summarized by Puigdomenech et al. (1997). The following includes a 
summary of material from that reference as well as the original papers it cites, and reference to some additional techniques not covered therein.

In addition to the extrapolations needed to estimate the temperature dependence of thermodynamic parameters, it is important to remember that most available low temperature experimental data are collected in high ionic strength solutions. Thus, $25^{\circ} \mathrm{C}$ thermodynamic parameters are also extrapolated (typically extrapolated to infinite dilution from high ionic strength experimental data). In effect, $25^{\circ} \mathrm{C}$ thermodynamic parameters themselves may be significantly limited and subject to significant uncertainties. In addition, there are inconsistencies in thermodynamic datasets derived from methodological differences among researchers and laboratories that contribute to the overall uncertainty of any extrapolations made from measured datasets.

General considerations with regard to temperature-dependent speciation include the following:

a) The dielectric constant of water decreases strongly with increasing temperature thereby favoring complexes of low or zero charge at higher temperatures, and making polynuclear complexes and highly charged complexes less favorable.

b) Hydrolysis of metals increases with increasing temperature in keeping with the increasing disproportionation of water with temperature.

c) For species where enthalpies of formation are known but for which there are no heat capacity data, it is usually possible to calculate equilibrium constants up to $100-150^{\circ} \mathrm{C}$ within a 1-2 log unit uncertainty resulting from neglecting the heat capacity.

d) New aqueous species that were not considered significant at $25^{\circ} \mathrm{C}$ may be significant at higher temperatures.

\subsection{Criss-Cobble Method}

Cecil Criss and J.W. Cobble determined a correspondence between experimental entropies of ions at a standard temperature and higher temperatures. Their principle of correspondence is summarized as follows (Criss and Cobble, 1964a):

A standard state can be chosen at every temperature such that the partial molal entropies of one class of ions at that temperature are linearly related to the corresponding entropies at some reference temperature.

$$
\mathrm{S}_{\left(\mathrm{t}_{2}\right)}^{\mathrm{O}}=\mathrm{a}_{\left(\mathrm{t}_{2}\right)}+\mathrm{b}_{\left(\mathrm{t}_{2}\right)} \mathrm{S}_{\left(\mathrm{t}_{1}\right)}^{\mathrm{O}}
$$

This principle results in abandoning the hydrogen ion convention and in setting non-zero values for the hydrogen ion that vary with temperature in order to create a linear relationship. They have defined values of $\mathrm{a}$ and $\mathrm{b}$ at various temperatures from linear fits to known data for different ion classes (Table 3 ).

From this principle, it also follows that whenever the entropy of an ion is known or can be accurately predicted at two temperatures, the average value of the heat capacity between those two temperatures, $\mathrm{C}_{\mathrm{p}}{ }^{\mathrm{o}}$ avg, also can be calculated, thereby allowing prediction of heat capacities 
for electrolytes over extended temperature ranges (Criss and Cobble, 1964b). This results from combining the following equation:

$$
\mathrm{C}_{\mathrm{p} \text { avg }}^{\mathrm{o}}=\frac{\underline{\mathrm{S}}_{\left(\mathrm{t}_{2}\right)}^{\mathrm{o}}-\mathrm{S}^{\mathrm{o}}\left(\mathrm{t}_{1}\right)}{\ln \mathrm{T}_{2} / \mathrm{T}_{1}}
$$

with the equation above to give:

$$
\left.\mathrm{C}_{\mathrm{p} \text { avg }}^{\mathrm{o}}=\quad \underline{\mathrm{a}}_{\left(\mathrm{t}_{2}\right)} \frac{-\mathrm{S}_{\left(\mathrm{t}_{1}\right)}^{\mathrm{o}}}{\ln \mathrm{T}_{2} / \mathrm{T}_{1}} \underline{\mathrm{t}}_{(\mathrm{t})}\right]
$$

which can be written as:

$$
\mathrm{C}_{\mathrm{p} \text { avg }}^{\mathrm{o}}=\alpha_{\left(\mathrm{t}_{2}\right)}-\beta_{\left(\mathrm{t}_{2}\right)} \mathrm{S}_{(25)}^{\mathrm{o}}
$$

where $\alpha_{\left(\mathrm{t}_{2}\right)}=\mathrm{a}_{\left(\mathrm{t}_{2}\right)} /\left(\ln \mathrm{T}_{2} / 298.2\right)$ and $\beta_{\left(\mathrm{t}_{2}\right)}=-\left[1.000-\mathrm{b}_{\left(\mathrm{t}_{2}\right)}\right] /\left(\ln \mathrm{T}_{2} / 298.2\right)$. They have defined values of $\alpha$ and $\beta$ at various temperatures from linear fits to known data for different ion classes (Table 4).

Table 3. Parameter values for calculating average heat capacities in cal $/ \mathrm{mol} / \mathrm{K}$ (Criss and Cobble, 1964b).

\begin{tabular}{|l|l|l|l|l|l|l|l|l|}
\hline & \multicolumn{3}{|l|}{ Cations } & \multicolumn{2}{l|}{$\begin{array}{l}\text { Anions and } \\
\mathbf{O H}^{-}\end{array}$} & \multicolumn{2}{l|}{ Oxy anions } & \multicolumn{2}{l|}{$\begin{array}{l}\text { Acid oxy } \\
\text { anions }\end{array}$} \\
\hline${ }^{\mathbf{0}} \mathbf{C}$ & $\mathbf{a}_{\left(\mathrm{t}_{2}\right)}$ & $\mathbf{b}_{\left(\mathrm{t}_{2}\right)}$ & $\mathbf{a}_{\left(\mathrm{t}_{2}\right)}$ & $\mathbf{b}_{\left(\mathrm{t}_{2}\right)}$ & $\mathbf{a}_{\left(\mathrm{t}_{2}\right)}$ & $\mathbf{b}_{\left(\mathrm{t}_{2}\right)}$ & $\mathbf{a}_{\left(\mathrm{t}_{2}\right)}$ & $\mathbf{b}_{\left(\mathrm{t}_{2}\right)}$ \\
\hline 60 & 35 & -0.41 & -46 & -0.28 & -127 & 1.96 & -122 & 3.44 \\
\hline 100 & 46 & -0.55 & -58 & 0 & -138 & 2.24 & -135 & 3.97 \\
\hline 150 & 46 & -0.59 & -61 & -0.03 & -133 & 2.27 & -143 & 3.95 \\
\hline 200 & 50 & -0.63 & -65 & -0.04 & -145 & 2.53 & -152 & 4.24 \\
\hline
\end{tabular}

Table 4. Estimated entropy parameters above $150^{\circ} \mathrm{C}$ by Criss-Cobble method (Criss and Cobble, 1964b).

\begin{tabular}{|l|l|l|l|l|l|l|l|l|}
\hline \multicolumn{3}{|l|}{ Cations } & \multicolumn{2}{l|}{$\begin{array}{l}\text { Anions and } \\
\text { OH }^{-}\end{array}$} & \multicolumn{2}{l|}{ Oxy anions } & \multicolumn{2}{l|}{$\begin{array}{l}\text { Acid oxy } \\
\text { anions }\end{array}$} \\
\hline${ }^{\mathbf{0}} \mathbf{C}$ & $\boldsymbol{\alpha}_{\left(\mathrm{t}_{2}\right)}$ & $\boldsymbol{\beta}_{\left(\mathrm{t}_{2}\right)}$ & $\boldsymbol{\alpha}_{\left(\mathrm{t}_{2}\right)}$ & $\boldsymbol{\beta}_{\left(\mathrm{t}_{2}\right)}$ & $\boldsymbol{\alpha}_{\left(\mathrm{t}_{2}\right)}$ & $\boldsymbol{\beta}_{\left(\mathrm{t}_{2}\right)}$ & $\boldsymbol{\alpha}_{\left(\mathrm{t}_{2}\right)}$ & $\boldsymbol{\beta}_{\left(\mathrm{t}_{2}\right)}$ \\
\hline 200 & 23.3 & 0.711 & -30.2 & 0.981 & -67.0 & 2.02 & -70.0 & 2.960 \\
\hline 250 & 29.9 & 0.630 & -38.7 & 0.978 & -86.5 & 2.32 & -90.0 & 3.530 \\
\hline 300 & 36.6 & 0.548 & -49.2 & 0.972 & -106 & 2.618 & & \\
\hline
\end{tabular}


The Criss-Cobble method of extrapolation can be used for any species where the entropy value at $25^{\circ} \mathrm{C}$ or another temperature is known.

In addition, Criss and Cobble have used the correspondence principle to come up with a linear equation to calculate ionic heat capacities at specific temperatures rather than over temperature ranges:

$$
\mathrm{C}_{\mathrm{pt}}^{\mathrm{o} t}=\mathrm{A}-\mathrm{BS}_{\mathrm{t}}^{\mathrm{o}}
$$

At $25^{\circ} \mathrm{C}$, the equation coefficients are shown in Table 5. As a test of the method, this equation can be utilized to calculate heat capacities at $25^{\circ} \mathrm{C}$ for ions where there are also heat capacity

Table 5: Criss-Cobble heat capacity parameters to calculate absolute heat capacities at $25^{\circ} \mathrm{C}$ in units of $\mathrm{cal} / \mathrm{mol} / \mathrm{K}$.

\begin{tabular}{|l|l|l|}
\hline \multicolumn{1}{|c|}{ Ion type } & \multicolumn{1}{c|}{ A } & \multicolumn{1}{c|}{ B } \\
\hline Cations & 41.6 & -0.523 \\
\hline OH-, anions & -56.5 & 0.179 \\
\hline Oxy anions & -145 & 2.2 \\
\hline Acid oxy anions & -135 & 3.07 \\
\hline
\end{tabular}

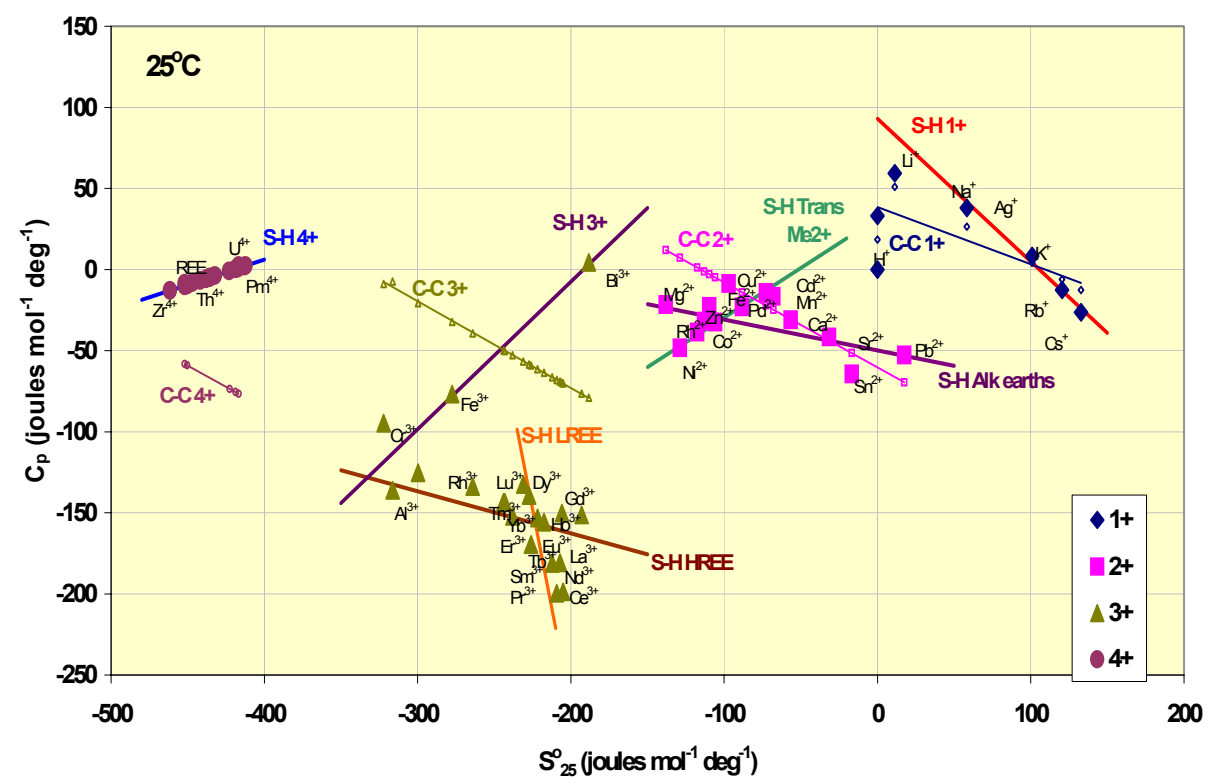

Figure 1: Comparison of Criss-Cobble(C-C) and Shock-Helgeson (S-H) calculated Cp trends for different groups of simple cations (labels denote groups of $1+, 2+, 3+$, and $4+$ cations, above) at $25^{\circ} \mathrm{C}$, with heat capacity data. Shock-Helgeson algorithms come from several references as described in text. The labels HREE and LREE refer respectively to heavy and light rare earth elements. 
data. Figure 1 shows data calculated by the Criss-Cobble method, adjusted from the absolute scale, and data from experiments or calculated by other methods. The discrepancy between the data and calculated values is particularly pronounced for trivalent and tetravalent cations, as was also noted previously (Shock and Helgeson, 1988), however, where multiple experimental data are available (e.g., $\mathrm{U}^{4+}$ ), there are also large discrepancies among the measured values.

\subsection{Helgeson-Flowers-Kirkham Method}

The approach of Helgeson et al. (1981) with revisions in subsequent publications (Shock and Helgeson, 1988; Shock et al., 1992; Shock et al., 1997a; Shock et al., 1997b) gives improved fits for lower valence cations $(1+, 2+$ and $3+)$ and provides a fit for tetravalent cations. The equation is equivalent to Equation 3-5 with coefficients as described in Table 6 . The resulting trends are shown in Figure 1 along with the results from the Criss-Cobble method.

Table 6. Coefficients for Equation 3-5 for heat capacity estimates from entropy at $25^{\circ} \mathrm{C}$ using the methods of Shock and Helgeson (1988), Shock et al (1997a, 1997b) Units of $\mathbf{c a l} / \mathbf{m o l} / \mathbf{K}$.

\begin{tabular}{|l|c|c|}
\hline \multicolumn{1}{|c|}{ Species } & A & B \\
\hline Monovalent simple cations & 22.2 & -0.88 \\
\hline Divalent simple transition metal cations & 7.5 & 0.61 \\
\hline Alkaline earth simple cations and $\mathrm{Pb}^{2+}$ & -11.9 & -0.19 \\
\hline Light rare earth simple trivalent cations & -298.8 & -4.9 \\
\hline Heavy rare earth simple trivalent cations and $\mathrm{Al}^{3+}$ & -51.3 & -0.26 \\
\hline Trivalent non- rare earth simple cations & 41.7 & 0.91 \\
\hline Tetravalent simple cations & 31.1 & 0.31 \\
\hline First monovalent cation hydroxide complex $(\mathrm{MOH})$ & 9 & -1.14 \\
\hline Second monovalent cation hydroxide complex $\left.(\mathrm{MO})^{-}\right)$ & -15.5 & -1.14 \\
\hline First divalent cation hydroxide complex $\left(\mathrm{MOH}^{+}\right)$ & 9 & -1.14 \\
\hline Second divalent cation hydroxide complex $\left(\mathrm{MO}^{+}\right)$ & -15.5 & -1.14 \\
\hline Third divalent cation hydroxide complex $\left(\mathrm{HMO}_{2}{ }^{-}\right)$ & -24 & -2.28 \\
\hline Fourth divalent cation hydroxide complex $\left(\mathrm{MO}_{2}^{2-}\right)$ & -106.2 & -2.28 \\
\hline First trivalent cation hydroxide complex $\left(\mathrm{MOH}^{2+}\right)$ & -37.2 & -1.14 \\
\hline Second trivalent cation hydroxide complex $\left(\mathrm{MO}^{+}\right)$ & -60.8 & -1.14 \\
\hline Third trivalent cation hydroxide complex $\left(\mathrm{HMO}_{2}\right)$ & -24 & -2.28 \\
\hline Fourth trivalent cation hydroxide complex $\left(\mathrm{MO}_{2}{ }^{-}\right)$ & -34.5 & -2.06 \\
\hline First tetravalent cation hydroxide complex $\left(\mathrm{MOH}^{3+}\right)$ & -37.2 & -1.14 \\
\hline Second tetravalent cation hydroxide complex $\left(\mathrm{MO}^{2+}\right)$ & -60.8 & -1.14 \\
\hline Third tetravalent cation hydroxide complex $\left(\mathrm{HMO}_{2}{ }^{+}\right)$ & -24 & -2.28 \\
\hline Fourth tetravalent cation hydroxide complex $\left(\mathrm{MO}_{2}\right)$ & -34.5 & -2.06 \\
\hline Fifth tetravalent cation hydroxide complex $\left(\mathrm{HMO}_{2}{ }^{-}\right)$ & -24 & -2.28 \\
\hline Halide ions & -28.2 & 0 \\
\hline Monovalent oxyanions & -62.4 & 1.32 \\
\hline Monovalent acid oxyanions & -37.7 & 1.32 \\
\hline Divalent oxyanions & -70.5 & 0.8 \\
\hline Divalent acid oxyanions & -51.5 & 0.8 \\
\hline
\end{tabular}


It is apparent from Figure 1 that the Shock-Helgeson equations give a better fit to existing data. Where rare earth elements appear to be good surrogates for the actinides, the appropriate ShockHelgeson fits may be used to estimate heat capacity data for actinide trivalent cations. With respect to higher valences, the coefficients suggested by Shock et al (1997a) give a calculated correlation for simple tetravalent cations that appears to be a better fit than the extension of the Criss-Cobble relationship defined for cations. However, this still leaves the outstanding problem of calculating heat capacities for pentavalent and hexavalent cations. $\mathrm{U}, \mathrm{Pu}$ and $\mathrm{Np}$ radionuclides are likely to be in these higher oxidation states in NTS waters.

In Figure 2, the correlations are reproduced along with calculated heat capacity values for actinides, $\mathrm{Am}^{2+}, \mathrm{Am}^{3+}, \mathrm{Pu}^{3+}, \mathrm{Np}^{3+}, \mathrm{U}^{3+}, \mathrm{U}^{4+}, \mathrm{Pu}^{4+}, \mathrm{Am}^{4+}$, and $\mathrm{Np}^{4+}$ using the Shock-Helgeson correlations. For the ions $\mathrm{Pu}^{3+}, \mathrm{U}^{3+}, \mathrm{U}^{4+}$, and $\mathrm{Pu}^{4+}$, heat capacity data also are available and these are also plotted (data also reported in Table 7). There is a large spread in these values and they do not correspond consistently with the calculated values although there is partial agreement between some reported and calculated values. Based on these results it appears that using either the Criss-Cobble or Shock-Helgeson algorithms to calculate heat capacity data is unwarranted even at $25^{\circ} \mathrm{C}$ for trivalent and tetravalent actinides. Algorithms currently do not exist that have been tested against known data for pentavalent and hexavalent cations, the oxidation states most pertinent for Np, U, and Pu under NTS groundwater conditions. Applying present generalized algorithms for cations to these higher oxidation state cations is not recommended given that the generalized Criss-Cobble algorithms appear not to capture the variability of trends even for

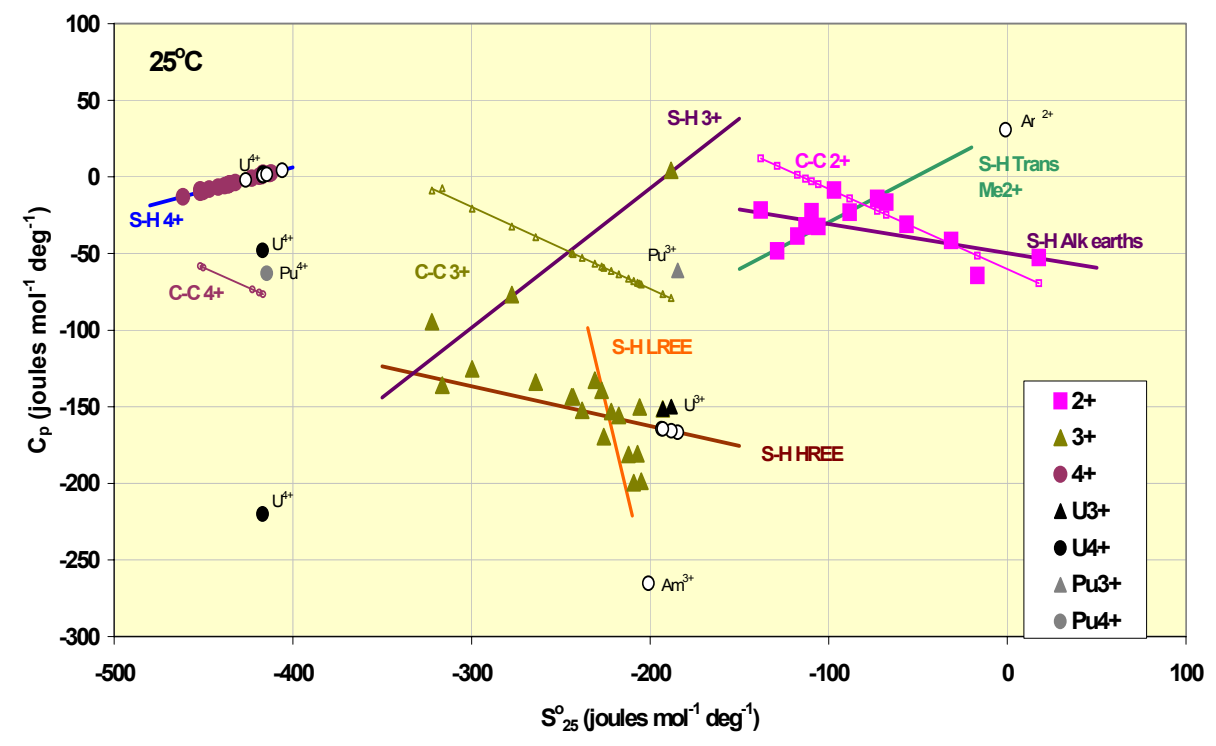

Figure 2: Calculations of heat capacity values using Shock-Helgeson algorithms for Am, $\mathrm{Pu}$, and $\mathrm{U}$ using available enthalpy data. Calculated values shown as white circles. Labels denote groups of 2+, 3+, and 4+ cations, heavy (HREE) and light (LREE) rare earth elements. For $\mathrm{Pu}$ and $\mathrm{U}$, there are some tabulated heat capacity data also. These data are plotted for comparison. The HREE algorithm was used for 3+ ions except for Am which is considered to have analogs with LREE, Ce and Eu. 
trivalent cations. The differences among the Shock-Helgeson coefficients for tetravalent cations and the variety of coefficient sets needed to define trends for trivalent cations suggest that attempts to estimate pentavalent and hexavalent trends, provided that entropy data could be obtained or estimated by other means, also is not a viable alternative until sufficient data become available to adequately test such estimates. To extend estimates made by these types of methods even further to higher temperatures would likely result in very high errors and erroneous conclusions regarding the impact of temperature.

Note that only simple cations have been discussed above; extrapolation appears to be even more speculative for complex cations and anions. Tables 5 and 6, respectively, show the Criss-Cobble and Shock-Helgeson coefficients for calculating heat capacity data for complex cations and anions. The model fits for these algorithms can only be compared against much smaller data sets. Again, they only extend up to complexes with tetravalent cations.

Table 7. Available thermodynamic data and calculated heat capacities for simple cations using the Shock-Helgeson family of coefficients shown in Table 4. The +/- columns list uncertainties in thermodynamic values. The number of significant figures reported is carried over from each reference. The heat capacities were calculated using the following equations: $\mathrm{Am}^{2+}$ : divalent transition metal cations; $\mathrm{Am}^{3+}$ : $\mathrm{LREE}$ trivalent; $\mathrm{Pu}^{3+}, \mathrm{Np}^{3+}, \mathrm{U}^{3+}$ : HREE trivalent; $\mathrm{Am}^{4+}, \mathrm{U}^{4+}, \mathrm{Pu}^{4+}, \mathrm{Np}^{4+}$ : tetravalent cations.

\begin{tabular}{|c|c|c|c|c|c|c|c|c|c|c|}
\hline Species & Reference & $\begin{array}{c}\Delta \mathbf{G}_{\mathrm{f}}^{0} \\
(\mathrm{~kJ} / \mathrm{mol} / \mathrm{K})\end{array}$ & $\begin{array}{c}\Delta \mathbf{G}_{\mathbf{f}}^{\mathbf{0}} \\
+/-\end{array}$ & $\begin{array}{c}\Delta \mathbf{H}_{\mathrm{f}}{ }^{0} \\
(\mathrm{~kJ} / \mathrm{mol} / \mathrm{K})\end{array}$ & $\begin{array}{c}\Delta \mathbf{H}_{\mathbf{f}}{ }^{\mathbf{0}} \\
+/-\end{array}$ & $\begin{array}{c}\mathbf{S}_{\mathbf{f}}{ }^{0} \\
(\mathrm{~J} / \mathbf{m o l} / \mathbf{K})\end{array}$ & $\begin{array}{l}\mathbf{S}_{\mathbf{f}}{ }^{0} \\
+/-\end{array}$ & $\begin{array}{c}\mathrm{C}_{\mathbf{p}}{ }^{0} \\
(\mathrm{~J} / \mathrm{mol} \mathrm{K})\end{array}$ & $\begin{array}{l}\mathbf{C}_{\mathbf{p}}{ }^{\mathbf{0}} \\
+/-\end{array}$ & $\begin{array}{l}\text { Calc. } \mathrm{C}_{\mathrm{p}}{ }^{0} \\
(\mathrm{~J} / \mathrm{mol} \mathrm{K})\end{array}$ \\
\hline $\mathrm{Am}^{2+}$ & 1 & -376.8 & 15.2 & -354.6 & 15.9 & -1 & 15 & & & 30.8 \\
\hline $\mathrm{Am}^{3+}$ & 2 & -598.7 & 4.8 & -616.7 & 1.5 & -201 & 15 & & & -265.3 \\
\hline $\mathrm{Pu}^{3+}$ & 1 & -579.0 & 2.7 & -591.8 & 2.0 & -184.5 & 6.2 & $-61^{*}$ & & -166.7 \\
\hline $\mathrm{Np}^{3+}$ & 1 & -512.9 & 5.7 & -527.2 & 2.1 & -193.6 & 20.3 & & & -164.3 \\
\hline $\mathrm{U}^{3+}$ & 1 & -476.5 & 1.8 & -489.1 & 3.7 & -188.2 & 13.9 & -150.0 & 50 & -165.7 \\
\hline $\mathrm{U}^{4+}$ & 3 & -529.9 & 1.8 & -591.2 & 3.3 & -416.9 & 12.6 & -48.0 & 15 & 0.9 \\
\hline $\mathrm{U}^{4+}$ & 2 & -529.9 & 1.8 & -591.2 & 3.3 & -416.9 & 12.6 & -220.0 & 50 & 0.9 \\
\hline $\mathrm{U}^{4+}$ & 4 & & & & & -416.7 & & 2.4 & & 0.9 \\
\hline $\mathrm{Pu}^{4+}$ & 2 & -478.0 & 2.7 & -539.9 & 3.1 & -414.5 & 10.2 & $-63^{*}$ & & 1.6 \\
\hline $\mathrm{Am}^{4+}$ & 1 & -346.4 & 8.7 & -406.0 & 6.0 & -406.0 & 21.0 & & & 4.3 \\
\hline $\mathrm{Np}^{4+}$ & 2 & -492.0 & 5.6 & -556.0 & 4.2 & -426.4 & 12.4 & & & -2.1 \\
\hline
\end{tabular}

1 Guillaumont, et al. (2003)

2 NEA Thermodynamic Database

3 Grenthe et al. (1992)

4 Wolery (personal communication)

*Data from Lemire and Tremaine (1980) 


\subsection{Density Model}

The density model is based on the observation that the change of the ionization constant for water with temperature up to $1000^{\circ} \mathrm{C}$ can be successfully modeled by an equation of the form:

$$
\log K=a+b / T+c / T^{2}+d / T^{3}+\left(e+f / T+g / T^{2}\right) \log \rho
$$

where $\rho$ is the density of water. A modified and simplified form of this equation was shown to successfully predict solute properties to about $300^{\circ} \mathrm{C}$ :

$$
\ln \mathrm{K}=\mathrm{p}_{1}+\mathrm{p}_{2} / \mathrm{T}+\left(\mathrm{p}_{3} \ln \rho\right) / \mathrm{T}
$$

where $\mathrm{p}_{1}, \mathrm{p}_{2}$ and $\mathrm{p}_{3}$ are constants, independent of temperature and pressure (Anderson et al., 1991; Mesmer et al., 1988). Since K also can be expressed as dependent on thermodynamic parameters of free energy, enthalpy, heat capacity and entropy, the constants above also can be expressed in terms of those thermodynamic parameters:

$$
\begin{aligned}
& \mathrm{p}_{1}=\ln \mathrm{K}_{\mathrm{r}}+\Delta \mathrm{H}_{\mathrm{r}}{ }^{\mathrm{o}} / \mathrm{RT}-\left(\Delta \mathrm{C}_{\mathrm{Pr}}{ }^{\mathrm{o}} \alpha_{\mathrm{r}}\right) /\left(\mathrm{RT}_{\mathrm{r}}(\delta \alpha / \delta \mathrm{T})_{\mathrm{Pr}}\right) \\
& \mathrm{p}_{2}=-\Delta \mathrm{H}_{\mathrm{r}}{ }^{\mathrm{o}} / \mathrm{R}+\left(\left(\mathrm{T}_{\mathrm{r}} \alpha_{\mathrm{r}}+\ln \rho_{\mathrm{r}}\right) \Delta \mathrm{C}_{\mathrm{Pr}}{ }^{\mathrm{o}}\right) /\left(\mathrm{RT}_{\mathrm{r}}(\delta \alpha / \delta \mathrm{T})_{\mathrm{Pr}}\right) \\
& \mathrm{p}_{3}=-\Delta \mathrm{C}_{\mathrm{Pr}}{ }^{o} /\left(\mathrm{RT}_{\mathrm{r}}(\delta \alpha / \delta \mathrm{T})_{\mathrm{Pr}}\right)
\end{aligned}
$$

These equations require knowing $\mathrm{K}_{\mathrm{r}}, \Delta \mathrm{H}_{\mathrm{r}}{ }^{\circ}$, and $\Delta \mathrm{C}_{\mathrm{Pr}}{ }^{\circ}$ for the reaction and looking up the values for the density and coefficient of thermal expansion for water, $\alpha$, at the temperature of interest. In addition to $\mathrm{K}$, other parameters can be calculated. For heat capacity at any temperature, the relation is:

$$
\Delta \mathrm{C}_{\mathrm{P}}{ }^{\mathrm{o}}=\Delta \mathrm{C}_{\mathrm{Pr}}^{\mathrm{o}}\left(\mathrm{T}(\delta \alpha / \delta \mathrm{T})_{\mathrm{P}} / \mathrm{T}_{\mathrm{r}}(\delta \alpha / \delta \mathrm{T}){ }_{\mathrm{Pr}}\right)
$$

The predicted heat capacity values at higher temperatures given specified heat capacity values at a reference state of $25^{\circ} \mathrm{C}$ are shown in Figure 3.

It is apparent from this figure that this model predicts that, when heat capacities at $25^{\circ} \mathrm{C}$ have low absolute values, the change with temperature also tends to be small. For these species, therefore, the temperature effect on the thermodynamic properties can be estimated to be small. In addition, over the temperature range from $25^{\circ} \mathrm{C}$ up to about $200^{\circ} \mathrm{C}$, the trends are relatively flat with temperature, changing rapidly only above about $200^{\circ} \mathrm{C}$. This would suggest that it is reasonable to estimate heat capacities as approximately constant with temperature over this temperature range. However, for the radionuclide ions and complexes of interest, there are few $\mathrm{C}_{\mathrm{p}}{ }^{\mathrm{o}}$ values at the $25^{\circ} \mathrm{C}$ reference state to draw on, and so this method is of little relevance for this study, but would be of great help should reference values become available. 


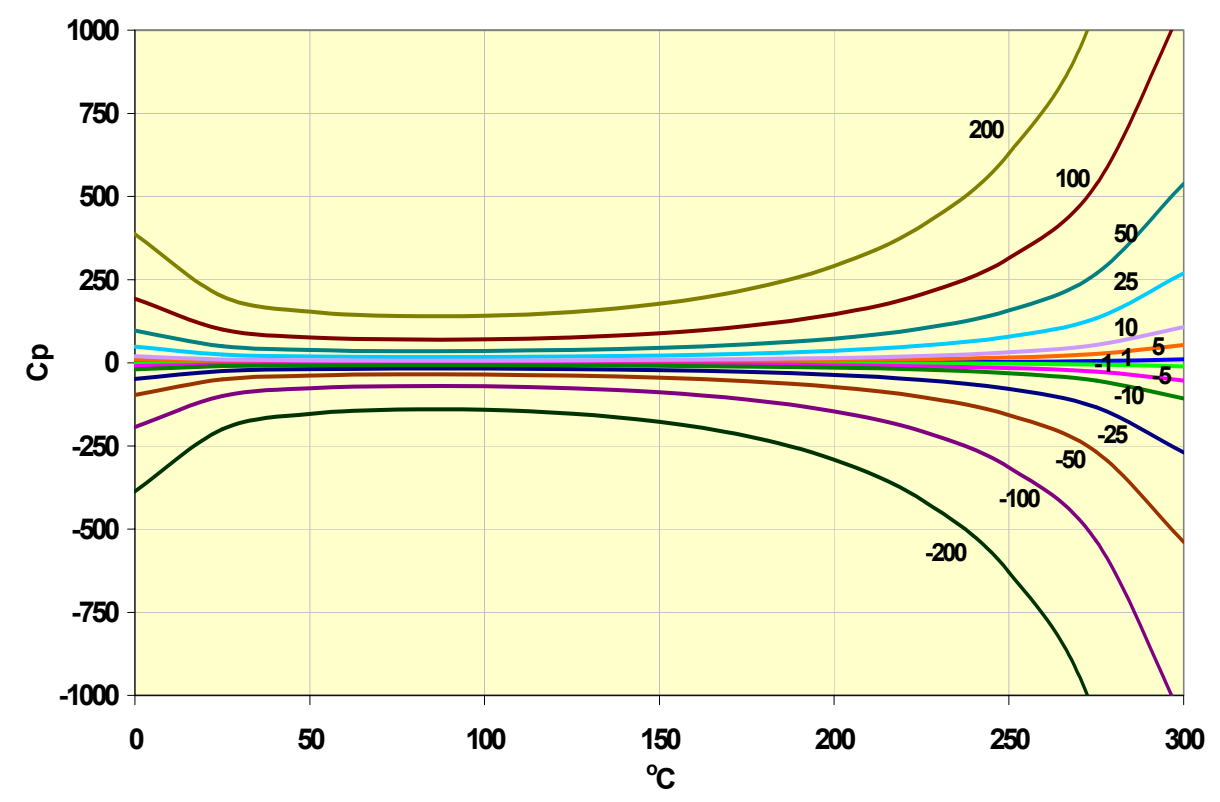

Figure 3: Calculation of heat capacity changes with temperature using the density model of Mesmer et al. (1988). The contours are labeled with values of heat capacities at $25^{\circ} \mathrm{C}$.

\subsection{Isoelectric or Isocoulombic Reaction Extrapolation}

For any reaction involving aqueous ionic species in which there is no oxidation/reduction component, the enthalpy of reaction is conceptually divisible into electrostatic and nonelectrostatic components (Anderson and Crerar, 1993; Puigdomenech et al., 1997). The major parts are the electrostatic interactions among the charged ions and between the charged ions and the solvent. As the dielectric constant of water increases with increasing temperature, electrostatic interactions become the largest contributors to the heat capacity of reaction.

Isoelectric or isocoulombic reactions are defined as those where the total amount of positive charge among the reactants equals the total amount of positive charge among the products, and the total amount of negative charge among reactants equals the total amount of negative charge among the products. In isoelectric reactions, the electrostatic contributions within the temperature component of enthalpy balance out, resulting in a small reaction heat capacity that is presumed to be close to constant with temperature. In fact, up to about $473 \mathrm{~K}$ (Puigdomenech et al., 1997), the integrated van't Hoff expression (constant enthalpy of reaction, zero heat capacity of reaction) appears to be reliable to calculate the change in the equilibrium constant due to temperature:

$$
\log _{10} \mathrm{~K}^{\mathrm{o}}(\mathrm{T})=\log _{10} \mathrm{~K}^{\mathrm{o}}\left(\mathrm{T}_{\mathrm{o}}\right)+\left(\Delta_{\mathrm{r}} \mathrm{H}_{\mathrm{m}}^{\mathrm{o}}\left(\mathrm{T}_{\mathrm{o}}\right) / \mathrm{R} \ln (10)\right)\left(1 / \mathrm{T}_{\mathrm{o}}-1 / \mathrm{T}\right)
$$

Up to about $623 \mathrm{~K}$, the equation also must include the heat capacity term (Puigdomenech et al., 1997): 


$$
\begin{aligned}
\log _{10} \mathrm{~K}^{\mathrm{o}}(\mathrm{T})= & \log _{10} \mathrm{~K}^{\mathrm{o}}\left(\mathrm{T}_{\mathrm{o}}\right)-\left(\Delta_{\mathrm{r}} \mathrm{H}_{\mathrm{m}}^{\mathrm{o}}\left(\mathrm{T}_{\mathrm{o}}\right) / \mathrm{R} \ln (10)\right)\left(1 / \mathrm{T}-1 / \mathrm{T}_{\mathrm{o}}\right)+ \\
& \left(\Delta_{\mathrm{r}} \mathrm{C}_{\mathrm{p}, \mathrm{m}}^{\mathrm{o}} / \mathrm{R} \ln (10)\right)\left[\left(\ln \left(\mathrm{T} / \mathrm{T}_{\mathrm{o}}\right)+\mathrm{T}_{\mathrm{o}}\left(1 / \mathrm{T}-1 / \mathrm{T}_{\mathrm{o}}\right)\right]\right.
\end{aligned}
$$

To derive the Gibbs free energies for individual ions requires setting up these reactions with species such that the other reaction components may be subtracted. This requires that the equilibrium constants for these other compounds be well known at higher temperatures. Thus, the choice of species to use for writing isocoulombic reactions is also limited by the availability and quality of data for the other ions.

\section{ANALOG SPECIES}

The trivalent actinides and lanthanides form chemical compounds and aqueous species that have similar chemical properties, including coordination chemistry and complex formation, but excluding redox behavior (Choppin and Rizkalla, 1994). Systematic trends in the thermodynamic data and equilibrium constants of the lanthanides and actinides often correlate with trends in ionic radius across the element groups. $\mathrm{Nd}(\mathrm{III}), \mathrm{Cm}(\mathrm{III})$, and $\mathrm{Eu}(\mathrm{III})$ are often used as analogs for Am(III) because of the similarity in ionic size. There are pronounced similarities and trends in most of the chemical properties of the actinide elements in the oxidation states $+4,+5$ and +6 . These correlations were used to estimate thermodynamic data for aqueous species of pentavalent and hexavalent $\mathrm{U}, \mathrm{Np}$ and $\mathrm{Pu}$ (Lemire et al., 2001) and for tetravalent actinides (Neck and Kim, 2001). The benefit of using these analogs is captured in the data included in the tables below that include values from Lemire et al. (2001), the subsequent NEA review by Guillaumont et al. (2003) and the NEA Thermodynamic Database (NEA-TDB) online http://www.nea.fr/html/dbtdb/).

The NEA review uses the oxidation state analogy principle as a justification for including experimental data for $\mathrm{Cm}$ (III) when evaluating thermodynamic data for aqueous Am(III) complexes (Guillaumont et al., 2003). Cm(III) data often are more accurate than data for Am(III) and there is a large amount of data on complex formation reactions of $\mathrm{Cm}$ (III) available from spectroscopic data obtained by time-resolved laser fluorescence spectroscopy (TRLFS). Based on their evaluations of literature data, they determined that differences in the activity coefficients and ion interaction coefficients of $\mathrm{Am}(\mathrm{III}), \mathrm{Cm}(\mathrm{III}), \mathrm{Nd}(\mathrm{III})$ and $\mathrm{Eu}(\mathrm{III})$ species are negligible and the differences in the formation constants of analogous aqueous complexes are in most cases smaller than experimental uncertainties.

\section{SUMMARY OF RADIONUCLIDE SPECIATION WITH TEMPERATURE BASED ON AVAILABLE DATA}

\subsection{Neptunium}

Guillaumont et al. (2003) examined new EXAFS data for $\mathrm{Np}$ that appeared after those discussed by Lemire et al. (2001). However, these results are not consistent with respect to hydration and 
coordination numbers and the values vary greatly from those obtained in previous studies. Guillaumont et al. (2003) concluded that the values published in the review by Lemire et al. (2001) should be retained. However, neither Lemire et al. (2001) nor Guillaumont et al. (2003) mention any reason for dropping the heat capacity values proposed by Lemire and Tremaine (1980) for $\mathrm{Np}^{4+}$ and $\mathrm{Np}^{3+}$. They have been retained herein. Kasuba and Runde (1999) also evaluated thermodynamic data for Np complexes. Values they list are the same as those listed herein, within the uncertainty limits. A summary of thermodynamic data is listed in Table 8 .

Table 8 shows the pertinent data for calculating isocoulombic speciation reactions as a function of temperature for reactions that involve $\mathrm{Np}$ and that would be relevant to NTS-type waters. ${ }^{2}$ Enthalpy data at $25^{\circ} \mathrm{C}$ necessary for temperature extrapolation using equations 3-12 or 3-13 are not available for two of the complexes, $\mathrm{Np}(\mathrm{OH})_{4}{ }^{0}$ and $\mathrm{NpO}_{2} \mathrm{CO}_{3}{ }^{-}$. For the $\mathrm{Np}^{4+} / \mathrm{NpO}_{2}{ }^{+}$redox reaction, we have heat capacity data for all species, so can compare the impact of using either equation. For $\mathrm{NpO}_{2} \mathrm{OH}^{0}$ and other complexes, we must use the equation that ignores heat capacity. The resulting calculations are shown in Table 9. It is important firstly to compare the $\log \mathrm{K}$ values at $25^{\circ} \mathrm{C}$ calculated using updated thermodynamic data to those used in the previous Cheshire HST simulations (Pawloski et al., 2001). In some cases, there is more discrepancy between the old and new $\log \mathrm{K}$ values at $25^{\circ} \mathrm{C}$ than between the $25^{\circ} \mathrm{C}$ value and values calculated for higher temperatures. Thus, it appears that the temperature effect at least in some cases is less than or comparable to the uncertainty in the values at $25^{\circ} \mathrm{C}$. The increase of $\log \mathrm{K}$ with temperature is found for the reaction involving $\mathrm{NpO}_{2} \mathrm{OH}^{0}$ where the high enthalpy value produces a 3 order-of-magnitude change in $\mathrm{K}$ from 25 to $150^{\circ} \mathrm{C}$. A similar effect is observed for $\mathrm{NpO}_{2}(\mathrm{OH})_{2}^{-}$. This is consistent with the idea that the relative stability of complexes with low charge will increase with temperature and that disproportionation of water will increase with temperature, favoring radionuclide hydrolysis. Interestingly, the $\log \mathrm{K}$ for $\mathrm{NpO}_{2}\left(\mathrm{CO}_{3}\right)_{3}{ }^{5-}$ decreases slightly with temperature. This is consistent with the decrease in the dielectric constant of water with temperature, favoring lower-charged species.

${ }^{2}$ Relevant reactions in this report refer primarily to carbonate complexes, hydroxide complexes, or redox reactions. These reactions were cited in Pawloski et al. (2001) as most relevant under NTS groundwater conditions. 
Table 8: Thermodynamic data for species and isocoulombic reactions involving Np. Data are from Guillaumont et al. (2003) except for heat capacity of $\mathrm{Np}^{4+}$ which is from Lemire and Tremaine (1980). The number of significant figures reported is carried over from each reference.

\begin{tabular}{|c|c|c|c|c|c|c|c|c|}
\hline Speciation Reactions Involving & $\Delta \mathbf{G}^{\mathbf{0}}$ & & $\Delta \mathbf{H}^{\mathbf{0}}$ & & $\Delta \mathbf{S}^{\mathbf{0}}$ & & $\Delta \mathbf{C}_{\mathrm{p}}{ }^{0}$ & \\
\hline Np used in Pawloski et al. (2001) & $\mathrm{kJ} / \mathrm{mol}$ & $+/-$ & $\mathrm{kJ} / \mathrm{mol}$ & $+1-$ & $\mathbf{J} / \mathbf{m o l ~ K}$ & $+/-$ & $\mathrm{J} / \mathrm{mol} \mathrm{K}$ & $+1-$ \\
\hline $\mathrm{Np}^{4+}+0.25 \mathrm{O}_{2}(\mathrm{~g})+1.5 \mathrm{H}_{2} \mathrm{O}=\mathrm{NpO}_{2}^{+}+3 \mathrm{H}^{+}$ & -60.2 & & 6.6 & & 224.3 & & -64.4 & \\
\hline $\mathrm{NpO}_{2}^{+}+\mathrm{H}_{2} \mathrm{O}=\mathrm{NpO}_{2} \mathrm{OH}^{0}+\mathrm{H}^{+}$ & 64.5 & & 64.8 & & 1.0 & & & \\
\hline $\mathrm{Np}^{4+}+4 \mathrm{H}_{2} \mathrm{O}=\mathrm{Np}(\mathrm{OH})_{4}{ }^{0}+4 \mathrm{H}^{+}$ & 47.6 & & & & & & & \\
\hline $\mathrm{NpO}_{2}^{+}+\mathrm{HCO}_{3}^{-}=\mathrm{NpO}_{2} \mathrm{CO}_{3}^{-}+\mathrm{H}^{+}$ & 30.7 & & & & & & & \\
\hline \multicolumn{9}{|l|}{$\begin{array}{l}\text { Relevant Species Available in the } \\
\text { Literature }\end{array}$} \\
\hline $\mathrm{Np}^{4+}$ & -491.8 & 5.6 & -556.0 & 4.2 & -426.4 & 12.4 & -60.0 & \\
\hline $\mathrm{O}_{2}$ & 0 & & 0 & & 205.2 & & 29.4 & \\
\hline $\mathrm{H}_{2} \mathrm{O}$ & -237.2 & & -285.8 & & 69.9 & & 75.4 & \\
\hline $\mathrm{NpO}_{2}^{+}$ & -907.8 & 5.6 & -978.2 & 4.6 & -45.9 & 10.7 & -4.0 & 25.0 \\
\hline $\mathrm{HCO}_{3}^{-}$ & -586.9 & & -689.9 & & 98.5 & & -35.4 & \\
\hline $\mathrm{NpO}_{2} \mathrm{CO}_{3}^{-}$ & -1464.0 & 5.7 & & & & & & \\
\hline $\mathrm{NpO}_{2} \mathrm{OH}^{0}$ & -1080.4 & 6.9 & -1199.2 & 19.2 & 25.0 & 60 & & \\
\hline $\mathrm{Np}(\mathrm{OH})_{4}{ }^{0}$ & -1392.9 & 8.4 & & & & & & \\
\hline $\mathrm{NpO}_{2}(\mathrm{OH})_{2}^{-}$ & -1247.3 & 6.3 & -1431.2 & 30.5 & 40.0 & 100.0 & & \\
\hline $\mathrm{NpO}_{2}\left(\mathrm{CO}_{3}\right)_{2}{ }^{3-}$ & -2000.9 & 5.7 & & & & & & \\
\hline $\mathrm{NpO}_{2}\left(\mathrm{CO}_{3}\right)_{3}{ }^{5-}$ & -2522.9 & 5.7 & -3017.1 & 6.9 & -135.1 & 20.5 & & \\
\hline
\end{tabular}


Table 9: Calculated log $K$ values using Equations 3-12 and 3-13 above. See text for discussion. Data used in calculations are shown in Table 8 . $^{1}$

\begin{tabular}{|c|c|c|c|c|c|c|c|c|c|c|c|}
\hline Speciation Reactions & \multicolumn{10}{|c|}{ Log K values $\left({ }^{\circ} \mathrm{C}\right)$} & \multirow[b]{2}{*}{ Notes } \\
\hline Involving Np & 0 & 25 & 50 & 60 & 75 & 100 & 150 & 200 & 250 & 300 & \\
\hline $\begin{array}{l}\mathrm{Np}^{4+}+0.25 \mathrm{O}_{2}(\mathrm{~g})+1.5 \mathrm{H}_{2} \mathrm{O} \\
=\mathrm{NpO}_{2}^{+}+3 \mathrm{H}^{+}\end{array}$ & 10.43 & 10.55 & 10.63 & 10.65 & 10.68 & 10.70 & 10.71 & 10.67 & 10.60 & 10.52 & $\begin{array}{c}\mathrm{Cp}= \\
\mathrm{Cp}^{\circ}\left(25^{\circ} \mathrm{C}\right)\end{array}$ \\
\hline \begin{tabular}{|l|} 
Same as above \\
\end{tabular} & 10.44 & 10.55 & 10.64 & 10.67 & 10.71 & 10.78 & 10.89 & 10.98 & 11.04 & 11.10 & $\mathrm{Cp}=0$ \\
\hline $\begin{array}{l}\mathrm{NpO}_{2}^{+}+\mathrm{H}_{2} \mathrm{O}=\mathrm{NpO}_{2} \mathrm{OH}^{0} \\
+\mathrm{H}^{+}\end{array}$ & -12.34 & -11.31 & -10.43 & -10.11 & -9.68 & -9.03 & -7.95 & -7.11 & -6.43 & -5.86 & $\mathrm{Cp}=0$ \\
\hline $\begin{array}{l}\mathrm{Np}^{4+}+4 \mathrm{H}_{2} \mathrm{O}=\mathrm{Np}(\mathrm{OH})_{4}{ }^{0} \\
+4 \mathrm{H}^{+}\end{array}$ & & -8.33 & & & & & & & & & \\
\hline $\begin{array}{l}\mathrm{NpO}_{2}^{+}+2 \mathrm{H}_{2} \mathrm{O}= \\
\mathrm{NpO}_{2}(\mathrm{OH})_{2}^{-}+2 \mathrm{H}^{+}\end{array}$ & -25.58 & -23.63 & -22.05 & -21.51 & -20.76 & -19.68 & -18.01 & -16.85 & -16.07 & -15.65 & $\mathrm{Cp}=0$ \\
\hline $\begin{array}{l}\mathrm{NpO}_{2}^{+}+\mathrm{HCO}_{3}^{-}= \\
\mathrm{NpO}_{2} \mathrm{CO}_{3}^{-}+\mathrm{H}^{+}\end{array}$ & & -5.38 & & & & & & & & & \\
\hline $\begin{array}{l}\mathrm{NpO}_{2}^{+}+2 \mathrm{HCO}_{3}^{-}= \\
\mathrm{NpO}_{2}\left(\mathrm{CO}_{3}\right)_{2}{ }^{3-}+2 \mathrm{H}^{+}\end{array}$ & & -14.14 & & & & & & & & & \\
\hline $\begin{array}{l}\mathrm{NpO}_{2}^{+}+3 \mathrm{HCO}_{3}^{-}= \\
\mathrm{NpO}_{2}\left(\mathrm{CO}_{3}\right)_{3}{ }^{5-}+3 \mathrm{H}^{+}\end{array}$ & -26.10 & -25.50 & -25.14 & -25.05 & -24.95 & -24.86 & -24.95 & -25.30 & -25.92 & -26.89 & $\mathrm{Cp}=0$ \\
\hline
\end{tabular}

1. Reactions written as isocoulombic reactions to calculate $\log \mathrm{K}$ but, if necessary, converted to a more consistent format in this table.

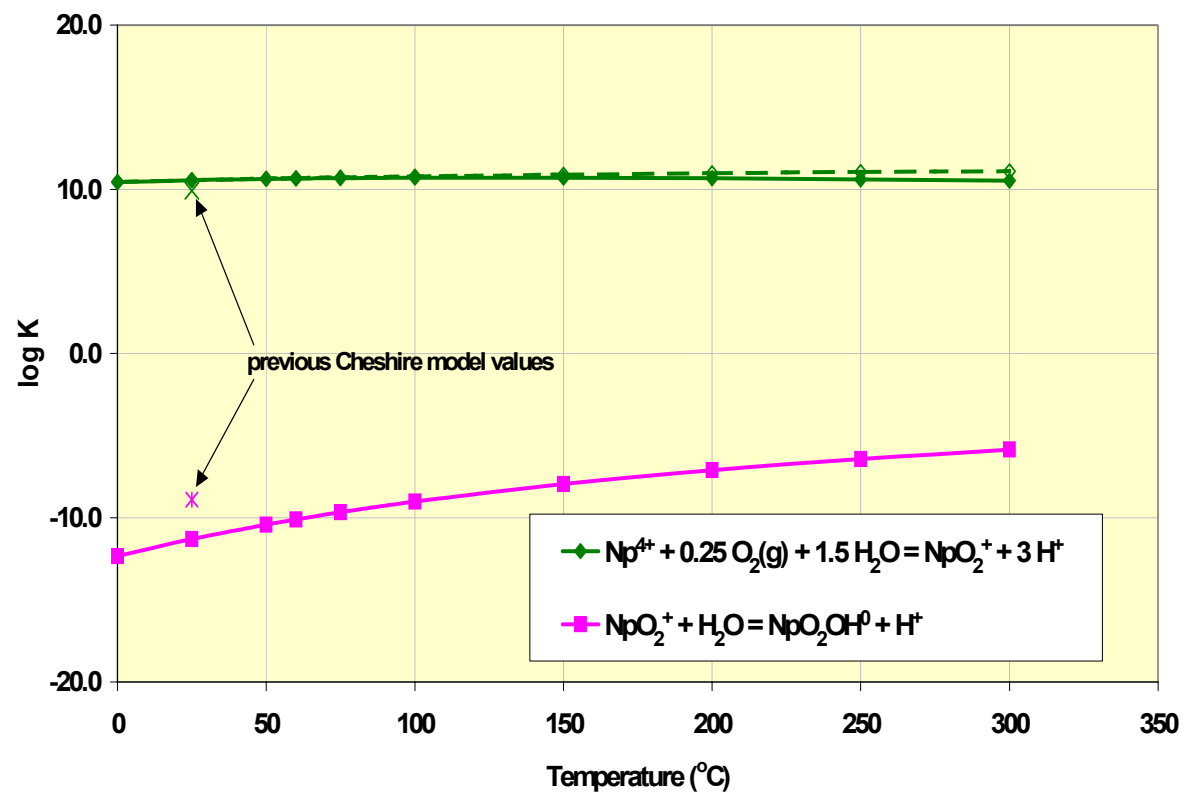

Figure 4: Plot of the temperature dependence of $\log \mathrm{K}$ for the two $\mathrm{Np}$ speciation reactions included in the Cheshire HST model. For the $\mathrm{Np}^{4+}$ to $\mathrm{NpO}_{2}{ }^{+}$reaction, both Eqs. 3-12 (solid line) and 3-13 (dashed line) were used. For the $\mathrm{NpO}_{2}{ }^{+}$to $\mathrm{NpO}_{2} \mathrm{OH}^{0}$ reaction, Eq. 3-12 was used. 


\subsection{Plutonium}

Lemire et al. (2001) had included data, which Guillaumont et al. (2003) now reject, to calculate free energy values for hydrolysis of tetravalent $\mathrm{Pu}$. The rejection is based on the fact that the total $\mathrm{Pu}$ concentration in those experiments exceeded the solubility of $\mathrm{PuO}_{2}(\mathrm{am})$.

Few data are available for plutonium species relevant under NTS groundwater conditions. Isocoulombic reactions were constructed for those species where there were sufficient data to calculate $\log \mathrm{K}$ values at higher temperatures. A large change with temperature was calculated for the reaction involving $\mathrm{Pu}(\mathrm{OH})_{4}{ }^{\mathrm{o}}$ and $\mathrm{PuO}_{2} \mathrm{OH}^{\circ}$, consistent with the increased hydrolysis of water. Only a small increase in $\log \mathrm{K}$ was predicted for the $\mathrm{PuO}_{2} \mathrm{CO}_{3}{ }^{-}$reaction. However, a significant decrease in $\log \mathrm{K}$ was predicted for the $\mathrm{PuO}_{2}\left(\mathrm{CO}_{3}\right)_{3}{ }^{5-}$ species, consistent with the results for $\mathrm{NpO}_{2}\left(\mathrm{CO}_{3}\right)_{3}{ }^{5-}$ and owing to the reduced dielectric constant of water with temperature.

Table 10: Thermodynamic data for species and isocoulombic reactions involving Pu. Data are from Guillaumont, et al. (2003) except for enthalpy data for $\mathrm{Pu}(\mathrm{OH})_{4(\mathrm{aq})}$ and $\mathrm{PuO}_{2}(\mathrm{OH})_{(\mathrm{aq})}$ which are from Lemire et al. (2001). The number of significant figures reported is carried over from each reference.

\begin{tabular}{|c|c|c|c|c|c|c|c|c|}
\hline $\begin{array}{c}\text { Radionuclide Speciation Reactions } \\
\text { used in Pawloski et al. (2001) }\end{array}$ & $\Delta \mathbf{G}_{\mathrm{r}}^{\mathbf{0}}$ & & $\Delta \mathbf{H}_{\mathrm{r}}^{0}$ & & $\Delta \mathbf{S}_{r}^{\mathbf{0}}$ & & $\Delta \mathbf{C}_{\mathrm{p}}{ }^{\mathrm{o}}$ & \\
\hline Involving Plutonium & $\mathrm{kJ} / \mathrm{mol}$ & $+/-$ & $\mathrm{kJ} / \mathrm{mol}$ & $+/-$ & $\mathrm{J} / \mathrm{mol} \mathrm{K}$ & $+/-$ & $\mathrm{J} / \mathrm{mol} \mathrm{K}$ & $+/-$ \\
\hline $\mathrm{Pu}^{4+}+4 \mathrm{H}_{2} \mathrm{O}=\mathrm{Pu}(\mathrm{OH})_{4}{ }^{\mathrm{o}}+4 \mathrm{H}^{+}$ & 48.7 & & 110.7 & & & & & \\
\hline $\mathrm{PuO}_{2}^{+}+\mathrm{HCO}_{3}^{-}=\mathrm{PuO}_{2} \mathrm{CO}_{3}^{-}+\mathrm{H}^{+}$ & 29.8 & & & & & & & \\
\hline $\begin{array}{l}\mathrm{PuO}_{2}{ }^{2+}+2 \mathrm{HCO}_{3}^{-}=\mathrm{PuO}_{2}\left(\mathrm{CO}_{3}\right)_{2}{ }^{2-}+ \\
2 \mathrm{H}^{-}\end{array}$ & 34.2 & & 2.4 & & -106.0 & & & \\
\hline $\begin{array}{l}\text { Relevant Species Available in the } \\
\text { Literature }\end{array}$ & & & & & & & & \\
\hline $\mathrm{Pu}^{4+}$ & -478.0 & 2.7 & -539.9 & 3.1 & -414.5 & 10.2 & -63.0 & \\
\hline $\mathrm{HCO}_{3}^{-}$ & -587.0 & & -689.9 & & 98.5 & & -35.4 & \\
\hline $\mathrm{H}_{2} \mathrm{O}$ & -237.2 & & -285.8 & & 69.9 & & 75.4 & \\
\hline $\mathrm{PuO}_{2} \mathrm{CO}_{3}^{-}$ & -1409.8 & 3.0 & & & & & & \\
\hline $\mathrm{PuO}_{2}\left(\mathrm{CO}_{3}\right)_{2}{ }^{2-}$ & -192.1 & 4.1 & -2199.5 & 7.7 & 19.6 & 27.7 & & \\
\hline $\mathrm{PuO}_{2}\left(\mathrm{CO}_{3}\right)_{3}{ }^{5-}$ & -2465.0 & 6.1 & -2954.9 & 12.3 & -116.4 & 45.0 & & \\
\hline $\mathrm{PuO}_{2}^{+}$ & -852.6 & 2.9 & -910.1 & 8.9 & 1.5 & 30.0 & & \\
\hline $\mathrm{PuO}_{2}{ }^{2+}$ & -762.4 & 2.8 & -822.0 & 6.6 & -71.2 & 22.1 & & \\
\hline $\mathrm{Pu}(\mathrm{OH})_{4}(\mathrm{aq})$ & -1378.0 & 3.9 & -1572.5 & & & & & \\
\hline $\mathrm{PuO}_{2} \mathrm{OH}(\mathrm{aq})$ & -1034.3 & & -1131.3 & & & & & \\
\hline
\end{tabular}


Table 11: Calculated log K values using Equations 3-12 above. See text for discussion. Data used in calculations are shown in Table 10. ${ }^{1}$

\begin{tabular}{|c|c|c|c|c|c|c|c|c|c|c|c|}
\hline $\begin{array}{c}\text { Radionuclide Speciation } \\
\text { Reactions }\end{array}$ & & & & & $\log K$ & $\left({ }^{\circ} \mathrm{C}\right)$ & & & & & Notes \\
\hline Involving Plutonium & 0 & 25 & 50 & 60 & 75 & 100 & 150 & 200 & 250 & 300 & \\
\hline $\begin{array}{l}\mathrm{Pu}^{4+}+4 \mathrm{H}_{2} \mathrm{O}=\mathrm{Pu}(\mathrm{OH})_{4}{ }^{0}+ \\
4 \mathrm{H}^{+}\end{array}$ & -10.30 & -8.53 & -7.03 & -6.49 & -5.74 & -4.63 & -2.80 & -1.35 & -0.19 & 0.78 & $\mathrm{Cp}=0$ \\
\hline $\mathrm{PuO}_{2}^{+}+\mathrm{H}_{2} \mathrm{O}=\mathrm{PuO}_{2} \mathrm{OH}^{\mathrm{o}}+\mathrm{H}^{+}$ & -10.76 & -9.72 & -8.85 & -8.53 & -8.10 & -7.45 & -6.38 & -5.54 & -4.86 & -4.29 & $\mathrm{Cp}=0$ \\
\hline $\mathrm{PuO}_{2}^{+}+\mathrm{HCO}_{3}^{-}=\mathrm{PuO}_{2} \mathrm{CO}_{3}^{-}+$ & & -5.22 & & & & & & & & & \\
\hline $\begin{array}{l}\mathrm{PuO}_{2}^{2+}+2 \mathrm{HCO}_{3}^{-}= \\
\mathrm{PuO}_{2}\left(\mathrm{CO}_{3}\right)_{2}^{2-}+2 \mathrm{H}^{+}\end{array}$ & -6.02 & -5.99 & -5.95 & -5.94 & -5.93 & -5.90 & -5.86 & -5.83 & -5.80 & -5.78 & $\mathrm{Cp}=0$ \\
\hline $\begin{array}{l}\mathrm{PuO}_{2}^{+}+3 \mathrm{HCO}_{3}^{-}= \\
\mathrm{PuO}_{2}\left(\mathrm{CO}_{3}\right)_{3}{ }^{5-}+3 \mathrm{H}^{+}\end{array}$ & -26.48 & -25.97 & -25.70 & -25.63 & -25.57 & -20 & -25.7 & -26.1 & -26. & -27.86 & $\mathrm{Cp}=0$ \\
\hline
\end{tabular}

1. Reactions written as isocoulombic reactions to calculate log K but, if necessary, converted to a more consistent format in this table.

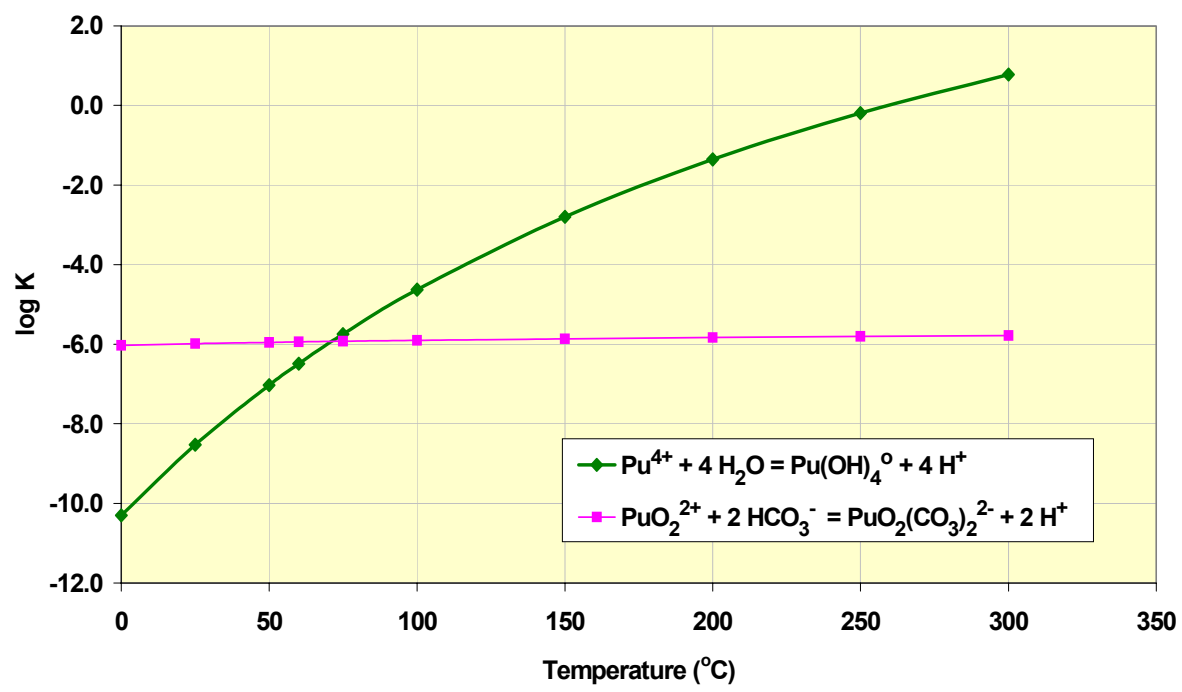

Figure 5: Plot of the temperature dependence of $\log K$ for two Pu speciation reactions. 


\subsection{Uranium}

According to Guillaumont et al. (2003) and substantiated by the literature search undertaken as part of this study, there are no new experimental thermodynamic data for uranium species beyond those already included in the NEA-TDB. However, Guillaumont et al. (2003) do include discussion of the issue also raised by these authors and others regarding the suitability of the Criss-Cobble method for cations at oxidation states of $3+$ and above. Lemire and Tremaine (1980) had used the Criss-Cobble relations to estimate the partial molar heat capacities of the $\mathrm{U}^{3+}$ and $\mathrm{U}^{4+}$ ions, and these were used in the NEA-TDB (Grenthe et al., 1992). These values are:

$$
\begin{aligned}
& \mathrm{C}_{p}\left(\mathrm{U}^{3+}\right)=-(64 \pm 22) \mathrm{J} / \mathrm{mol} / \mathrm{K}(T=298 \text { to } 473 \mathrm{~K}), \\
& \mathrm{C}_{p}\left(\mathrm{U}^{4+}\right)=-(48 \pm 15) \mathrm{J} / \mathrm{mol} / \mathrm{K}(T=298 \text { to } 473 \mathrm{~K}) .
\end{aligned}
$$

The Shock and Helgeson (1988) estimation methods based on the revised Helgeson-KirkhamFlowers (HKF) equations of state for aqueous ions result in calculation of:

$$
\begin{aligned}
& \mathrm{C}_{p}^{\mathrm{o}}\left(\mathrm{U}^{3+}, 298.15 \mathrm{~K}\right)=-152.3 \mathrm{~J} / \mathrm{mol} / \mathrm{K} \\
& \mathrm{C}^{\mathrm{o}}{ }_{p}\left(\mathrm{U}^{4+}, 298.15 \mathrm{~K}\right)=0.8 \mathrm{~J} / \mathrm{mol} / \mathrm{K}
\end{aligned}
$$

The latter value was based on the experimental result $\mathrm{C}_{\mathrm{m} p}^{\mathrm{o}}\left(\mathrm{Th}^{4+}, 298.15 \mathrm{~K}\right)=-(1 \pm 11)$ $\mathrm{J} / \mathrm{mol} / \mathrm{K}$ by Morss and McCue (1976) which has since been revised to $=-(224 \pm 5) \mathrm{J} / \mathrm{mol} / \mathrm{K}$ (Hovey, 1997). In light of this new data and several other considerations, Guillaumont et al. (2003) adopted new values of:

$$
\begin{aligned}
& \mathrm{C}_{p}^{\mathrm{o}}\left(\mathrm{U}^{3+}, 298.15 \mathrm{~K}\right)=-(150 \pm 50) \mathrm{J} / \mathrm{mol} / \mathrm{K} \\
& \mathrm{C}^{\mathrm{o}}{ }_{p}\left(\mathrm{U}^{4+}, 298.15 \mathrm{~K}\right)=-(220 \pm 50) \mathrm{J} / \mathrm{mol} / \mathrm{K} .
\end{aligned}
$$

They note that the large uncertainties are due partly to the fact that the comparison between average values for the temperature range 298.15 to $473 \mathrm{~K}$ with values at $298.15 \mathrm{~K}$ is not strictly correct and suggest that the selected heat capacity values not be used at temperatures above 373 $\mathrm{K}$. Note however, that while the $3+$ value appears to fit well with predictions and the trends for other trivalent data, the fit of heat capacity value for the 4+ species fits poorly compared to other data and the general trend for tetravalent cations (Figure 2).

Only some selected equilibrium constants have been updated recently. For U(IV), the hydrolysis of $\mathrm{U}^{4+}$ has been reviewed according to the behavior of the other aqueous actinide (IV) ions. New equilibrium constants have been selected by Guillaumont et al. (2003).

These changes in thermodynamic values result in relatively small changes in the equilibrium constants at $25^{\circ} \mathrm{C}$ from the values used in Pawloski et al. (2001). For isocoulombic reactions, the calculations of the temperature effect are shown in Table 13 and plotted in Figure 6. Tables 12 and 13 also include several reactions that were not included in GIMRT simulations of Pawloski et al. (2001) based on the fact that the $\mathrm{UOH}^{3+}$ and $\mathrm{U}(\mathrm{OH})_{4}{ }^{\circ}$ species are not predicted to be dominant at the $\mathrm{pH}$ range of NTS groundwater at $25^{\circ} \mathrm{C}$. However, because these species had data available for temperature extrapolations, and the $\mathrm{pH}$ effect on species dominance will shift with 
temperature, they are included here. Nevertheless, the number of species that can be extrapolated to temperature is not sufficient to create meaningful $\mathrm{pH}$-Eh stability diagrams. Qualitatively, we find that the behavior of $\mathrm{U}(\mathrm{VI})$ species is similar to $\mathrm{Np}(\mathrm{V})$ and $\mathrm{Pu}(\mathrm{V})$ : complexed species with low charge tend to be favored with increasing temperature.

Table 12: Thermodynamic data for species and isocoulombic reactions involving $U$. Data are from Guillaumont, et al. (2003). The number of significant figures reported is carried over from each reference.

\begin{tabular}{|c|c|c|c|c|c|c|c|c|}
\hline Radionuclide Speciation Reactions & $\Delta \mathbf{G}^{\mathbf{0}}$ & & $\Delta \mathbf{H}^{\mathbf{0}}$ & & $\Delta S^{0}$ & & $\Delta \mathbf{C}_{\mathrm{p}}{ }^{\mathbf{0}}$ & \\
\hline $\begin{array}{c}\text { Used in Pawloski et al. (2001) } \\
\text { Involving Uranium }\end{array}$ & $\mathrm{kJ} / \mathrm{mol}$ & $+/-$ & $\mathrm{kJ} / \mathrm{mol}$ & $+/-$ & $\mathrm{J} / \mathrm{mol} \mathrm{K}$ & $+/-$ & $\mathrm{J} / \mathrm{mol} \mathrm{K}$ & $+/-$ \\
\hline $\mathrm{U}^{4+}+\mathrm{H}_{2} \mathrm{O}=\mathrm{UOH}^{3+}+\mathrm{H}^{+}$ & 3.12 & & 46.910 & & 147.026 & & & \\
\hline $\mathrm{U}^{4+}+4 \mathrm{H}_{2} \mathrm{O}=\mathrm{U}(\mathrm{OH})_{4}{ }^{0}+4 \mathrm{H}^{+}$ & 57.28 & & 109.913 & & 177.203 & & 123.558 & \\
\hline $\mathrm{UO}_{2}{ }^{2+}+2 \mathrm{HCO}_{3}{ }^{-}=\mathrm{UO}_{2}\left(\mathrm{CO}_{3}\right)_{2}{ }^{2-}+2 \mathrm{H}^{+}$ & 23.27 & & 47.906 & & 83.147 & & & \\
\hline $\mathrm{UO}_{2}^{2+}+2 \mathrm{H}^{+=} \mathrm{U}^{4+}+0.5 \mathrm{O}_{2}(\mathrm{~g})+\mathrm{H}_{2} \mathrm{O}$ & 185.51 & & 141.970 & & -146.196 & & -172.350 & \\
\hline \multicolumn{9}{|l|}{$\begin{array}{l}\text { Relevant Species Available in the } \\
\text { Literature }\end{array}$} \\
\hline $\mathrm{U}^{4+}$ & -529.86 & 1.765 & -591.200 & 3.300 & -416.895 & 12.553 & -220.000 & 50.000 \\
\hline $\mathrm{O}_{2}$ & 0 & & 0 & & 205.152 & & 29.378 & \\
\hline $\mathrm{H}_{2} \mathrm{O}$ & -237.18 & & -285.830 & & 69.923 & & 75.361 & \\
\hline $\mathrm{HCO}_{3}^{-}$ & -586.94 & & -689.933 & & 98.450 & & -35.397 & \\
\hline $\mathrm{UO}_{2}^{2+}$ & -952.55 & 1.747 & -1019.000 & 1.500 & -98.200 & 3.000 & 42.400 & 3.000 \\
\hline $\mathrm{UOH}^{3+}$ & -763.92 & 1.798 & -830.12 & 9.54 & -199.946 & 32.521 & & \\
\hline $\mathrm{UO}_{2} \mathrm{OH}^{+}$ & -1159.7 & 2.2 & -1261.4 & 15.1 & 17.0 & 50.0 & & \\
\hline $\mathrm{UO}_{2}(\mathrm{OH})_{2}(\mathrm{aq})$ & -1357.5 & 1.8 & & & & & & \\
\hline $\mathrm{UO} 2(\mathrm{OH})_{3}^{-}$ & -1548.4 & 3.0 & & & & & & \\
\hline $\mathrm{UO}_{2} \mathrm{CO}_{3(\mathrm{aq})}$ & -1537.2 & 1.8 & -1689.2 & 2.5 & 58.9 & 7.4 & & \\
\hline $\mathrm{UO}_{2(} \mathrm{CO}_{3 / 2}{ }^{2-}$ & -2103.16 & 1.982 & -2350.960 & 4.301 & 181.846 & 13.999 & & \\
\hline $\mathrm{UO}_{2(} \mathrm{CO}_{3) 3}{ }^{4-}$ & -2660.91 & 2.116 & -3083.890 & 4.430 & 38.446 & 14.411 & & \\
\hline $\mathrm{U}(\mathrm{OH})_{4}{ }^{0}$ & -1421.31 & 8.189 & \begin{tabular}{|l|}
-1624.61 \\
\end{tabular} & 11.073 & 40.000 & 25.000 & 205.000 & 80.000 \\
\hline
\end{tabular}


Table 13: Calculated $\log K$ values using Equations 3-12 and 3-13 above. See text for discussion. Data used in calculations are shown in Table 12. ${ }^{1}$

\begin{tabular}{|c|c|c|c|c|c|c|c|c|c|c|c|}
\hline $\begin{array}{c}\text { Radionuclide Speciation } \\
\text { Reactions }\end{array}$ & & & & & $\log K$ & $\left({ }^{\circ} \mathrm{C}\right)$ & & & & & \\
\hline Involving Uranium & 0 & 25 & 50 & 60 & 75 & 100 & 150 & 200 & 250 & 300 & Notes \\
\hline $\mathrm{U}^{4+}+\mathrm{H}_{2} \mathrm{O}=\mathrm{UOH}^{3+}+\mathrm{H}^{+}$ & -1.299 & -0.547 & 0.089 & 0.316 & 0.633 & 1.104 & 1.880 & 2.492 & 2.987 & 3.395 & $\mathrm{Cp}=0$ \\
\hline $\mathrm{UO}_{2}{ }^{2+}+\mathrm{H}_{2} \mathrm{O}=\mathrm{UO}_{2} \mathrm{OH}^{+}+\mathrm{H}^{+}$ & -5.96 & -5.26 & -4.67 & -4.46 & -4.17 & -3.73 & -3.01 & -2.45 & -1.99 & -1.61 & \\
\hline $\begin{array}{l}\mathrm{UO}_{2}{ }^{2+}+2 \mathrm{H}_{2} \mathrm{O}=\mathrm{UO}_{2}(\mathrm{OH})_{2}{ }^{0}+ \\
2 \mathrm{H}^{+}\end{array}$ & & -12.16 & & & & & & & & & \\
\hline $\begin{array}{l}\mathrm{UO}_{2}{ }^{2+}+3 \mathrm{H} 2 \mathrm{O}=\mathrm{UO}_{2}(\mathrm{OH})_{3}{ }^{-}+ \\
3 \mathrm{H}^{+}\end{array}$ & & -20.27 & & & & & & & & & \\
\hline $\mathrm{U}^{4+}+4 \mathrm{H}_{2} \mathrm{O}=\mathrm{U}(\mathrm{OH})_{4}{ }^{\mathrm{o}}+4 \mathrm{H}^{+}$ & -11.795 & -10.033 & -8.543 & -8.010 & -7.268 & -6.163 & -4.345 & -2.912 & -1.752 & -0.795 & $\mathrm{Cp}=0$ \\
\hline Same as above & -11.769 & -10.033 & -8.523 & -7.972 & -7.194 & -6.012 & -3.992 & -2.319 & -0.899 & 0.326 & $\begin{array}{c}\mathrm{Cp}=0 \\
\mathrm{Cp}^{\circ}\left(25^{\circ} \mathrm{C}\right)\end{array}$ \\
\hline $\mathrm{UO}_{2}{ }^{2+}+\mathrm{HCO}_{3}{ }^{-}=\mathrm{UO}_{2} \mathrm{CO}_{3}{ }^{0}+$ & -0.67 & -0.40 & -0.10 & 0.02 & 0.21 & 0.52 & 1.14 & 1.78 & 2.46 & 3.25 & $\mathrm{Cp}=0$ \\
\hline $\begin{array}{l}\mathrm{UO}_{2}{ }^{2+}+2 \mathrm{HCO}_{3}^{-}= \\
\mathrm{UO}_{2}\left(\mathrm{CO}_{3}\right)_{2}{ }^{2-}+2 \mathrm{H}^{+}\end{array}$ & -4.844 & -4.076 & -3.427 & -3.194 & -2.871 & -2.389 & -1.597 & -0.972 & -0.467 & -0.050 & $\mathrm{Cp}=0$ \\
\hline $\begin{array}{l}\mathrm{UO}_{2}{ }^{2+}+3 \mathrm{HCO}_{3}^{-}= \\
\mathrm{UO}_{2}\left(\mathrm{CO}_{3}\right)_{3}{ }^{4-}+3 \mathrm{H}^{+}\end{array}$ & -9.32 & -9.19 & -9.16 & -9.16 & -9.18 & -9.24 & -9.46 & -9.78 & -10.20 & -10.77 & $\mathrm{Cp}=0$ \\
\hline $\begin{array}{l}\mathrm{UO}_{2}^{2+}+2 \mathrm{H}^{+=} \mathrm{U}^{4+}+0.5 \mathrm{O}_{2}(\mathrm{~g}) \\
+\mathrm{H}_{2} \mathrm{O}\end{array}$ & -34.770 & -32.494 & -30.570 & -29.882 & -28.923 & -27.496 & -25.148 & -23.297 & -21.799 & -20.563 & $\mathrm{Cp}=0$ \\
\hline Same as above & -34.806 & -32.494 & -30.599 & -29.935 & -29.026 & -27.707 & -25.641 & -24.124 & -22.989 & -22.127 & $\begin{array}{c}\mathrm{Cp}= \\
\mathrm{Cp}^{\circ}\left(25^{\circ} \mathrm{C}\right)\end{array}$ \\
\hline
\end{tabular}

1. Reactions written as isocoulombic reactions to calculate $\log \mathrm{K}$ but, if necessary, converted to a more consistent format in this table.

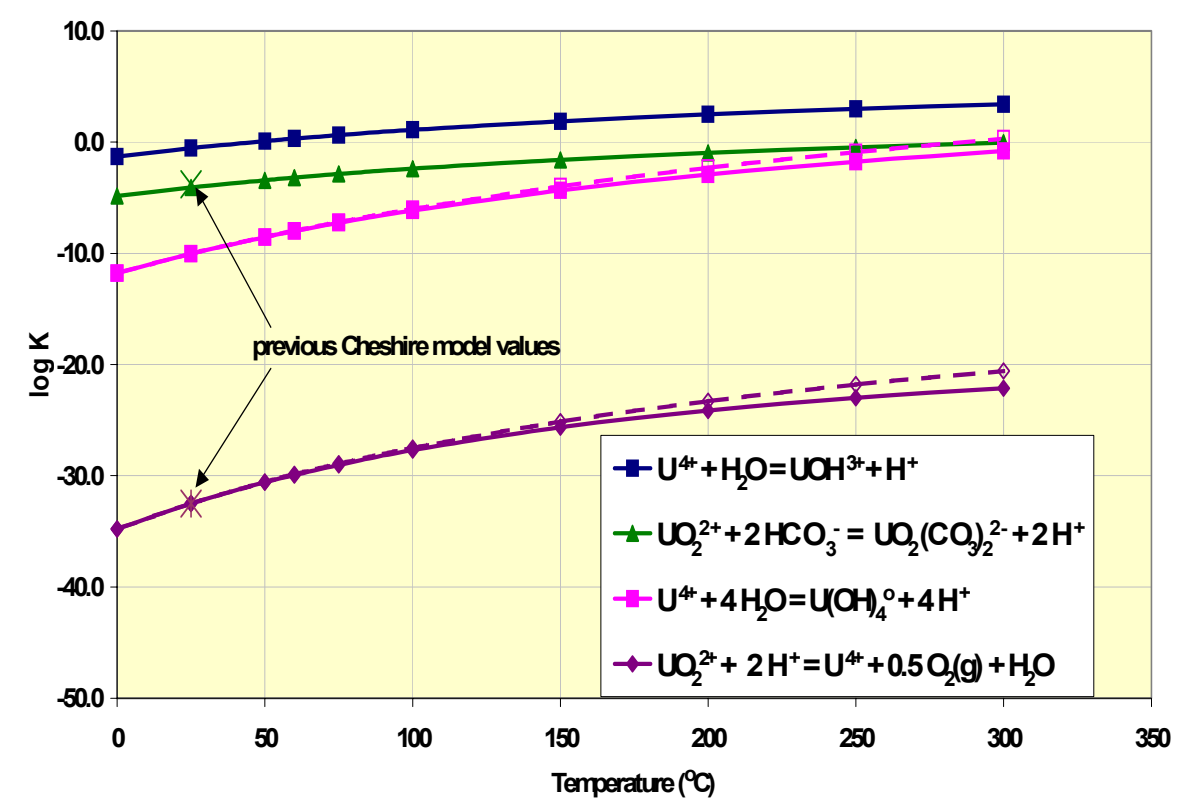

Figure 6: Plot of the temperature dependence of $\log \mathrm{K}$ for selected $\mathrm{U}$ speciation reactions. 


\subsection{Americium}

The Cheshire HST model simulations (Pawloski et al., 2001) included 4 americium species, $\mathrm{AmCO}_{3}{ }^{+}, \mathrm{Am}\left(\mathrm{CO}_{3}\right)_{2}{ }^{-}, \mathrm{Am}(\mathrm{OH})_{2}{ }^{+}$, and $\mathrm{AmOH}^{2+}$ within which Am is in the $3+$ state.

Guillaumont et al. (2003) have selected some new data for Am hydroxides based on both the studies already discussed in Silva et al. (1995) and the large amount of new experimental data for Am(III) and Cm(III) hydroxide complexes. These new data result in shifts in the equilibrium constants at $25^{\circ} \mathrm{C}$ for the two Am-hydroxide complexes used in Cheshire HST simulations as shown in Table 14. Unfortunately, these new studies did not result in any enthalpy, entropy or heat capacity data for these species, so calculation of higher temperature reaction constants is not possible based on currently accepted algorithms. The data of Wruck and Palmer (1997), which included equilibrium values for $\mathrm{AmCO}_{3}{ }^{+}$at temperatures of 25,50 and $75^{\circ} \mathrm{C}$ using pulsed laser photoacoustic spectroscopy, are included in the Guillaumont et al. (2003) assessment. When the Wruck and Palmer (1997) value is corrected to zero ionic strength at $25^{\circ} \mathrm{C}$, it is in the lower part of the range of values determined by other studies ( $\log \mathrm{K}^{\mathrm{o}}$ ranging from $\left.7.3-10\right)$. Guillaumont et al. (2003) concluded that $\log \mathrm{K}=7.8 \pm 0.3$ was a reasonable value. The values of Wruck et al. (1997) for $\log \mathrm{K}$ for $\mathrm{AmCO}_{3}{ }^{+}$are $6.26 \pm 0.12\left(25^{\circ} \mathrm{C}\right), 6.68 \pm 0.12\left(50^{\circ} \mathrm{C}\right)$ and $7.54 \pm 0.43\left(75^{\circ} \mathrm{C}\right)$; these are not corrected to zero ionic strength. They also calculated an enthalpy of reaction of 11 $\mathrm{kJ} / \mathrm{mol}$, larger than anticipated by comparison with the Eu-carbonate complex (Wruck et al., 1999). The Wruck et al. (1999) enthalpy value was not included in the NEA-TDB, but has been used to calculate an enthalpy value for the associated reaction shown in Table 14. However, even with its inclusion, we do not have sufficient data to use present algorithms to extend the $\log \mathrm{K}$ values to temperatures above $75^{\circ} \mathrm{C}$.

Table 14: Thermodynamic data for Am species. Data are from Guillaumont, et al. (2003) with the exception of the enthalpy value for the reaction involving $\mathrm{AmCO}_{3}{ }^{+}$, which was derived from Wruck et al. (1999). The number of significant figures reported is carried over from each reference.

\begin{tabular}{|c|c|c|c|c|c|c|c|c|c|}
\hline Radionuclide Speciation Reactions & $\Delta \mathbf{G}^{\mathbf{0}}$ & & $\Delta \mathbf{H}^{\mathbf{0}}$ & & $\Delta \mathbf{S}^{0}$ & & $\Delta \mathbf{C}_{\mathrm{p}}{ }^{\mathbf{0}}$ & & \\
\hline $\begin{array}{c}\text { Used in Pawloski et al. (2001) Involving } \\
\text { Americium } \\
\end{array}$ & $\mathrm{kJ} / \mathrm{mol}$ & $+/-$ & $\mathrm{kJ} / \mathrm{mol}$ & $+/-$ & $\mathbf{J} / \mathbf{m o l ~ K}$ & $+/-$ & $\mathrm{J} / \mathrm{mol} \mathrm{K}$ & $+/-$ & $\begin{array}{l}\log K \\
\left(25^{\circ} \mathrm{C}\right) \\
\end{array}$ \\
\hline $\mathrm{Am}^{3+}+2 \mathrm{H}_{2} \mathrm{O}=\mathrm{Am}(\mathrm{OH})_{2}^{+}+2 \mathrm{H}^{+}$ & 86.274 & & & & & & & & -15.112 \\
\hline $\mathrm{Am}^{3+}+\mathrm{H}_{2} \mathrm{O}=\mathrm{AmOH}^{2+}+\mathrm{H}^{+}$ & 41.139 & & & & & & & & -7.206 \\
\hline $\mathrm{Am}^{3+}+2 \mathrm{HCO}_{3}{ }^{-}=\mathrm{Am}\left(\mathrm{CO}_{3}\right)_{2}{ }^{-}+2 \mathrm{H}^{+}$ & 44.447 & & & & & & & & -7.785 \\
\hline $\mathrm{Am}^{3+}+\mathrm{HCO}_{3}^{-}=\mathrm{AmCO}_{3}^{+}+\mathrm{H}^{+}$ & 13.376 & & 25.7 & & & & & & -2.343 \\
\hline \multicolumn{10}{|l|}{\begin{tabular}{|l} 
Relevant Species Available in the \\
Literature
\end{tabular}} \\
\hline $\mathrm{Am}^{3+}$ & -598.698 & 4.754 & -616.7 & 1.5 & -201 & 15 & & & \\
\hline $\mathrm{Am}(\mathrm{OH})_{2}^{+}$ & -986.787 & 6.211 & & & & & & & \\
\hline $\operatorname{Am}\left(\mathrm{CO}_{3}\right)_{2}^{-}$ & -1728.131 & 5.911 & & & & & & & \\
\hline $\mathrm{H}_{2} \mathrm{O}$ & -237.181 & & -285.830 & & 69.923 & & 75.361 & & \\
\hline $\mathrm{HCO}_{3}^{-}$ & -586.940 & & -689.933 & & 98.450 & & -35.397 & & \\
\hline $\mathrm{AmOH}^{2+}$ & -794.74 & 5.546 & & & & & & & \\
\hline $\mathrm{AmCO}_{3}{ }^{+}$ & -1172.262 & 5.289 & & & & & & & \\
\hline
\end{tabular}




\section{IMPLICATIONS FOR MOBILITY OF RADIONUCLIDES}

In general, where data are available to calculate higher temperature values, the $\log \mathrm{K}$ values for the complexation reactions increase with increasing temperature. Because increased aqueous complexation may enhance mobility (particularly in the case of carbonate complexation) by allowing species to stay in solution, radionuclide transport may be enhanced with increasing temperature. By using constant $\log \mathrm{K}$ values, the mobility may, in fact, be underestimated. However, many other competing effects need to be taken into account to evaluate the effect of temperature on radionuclide mobility, as described below.

Many of the complexation reactions involve $\mathrm{H}^{+}$ions and reactant species such as carbonate or bicarbonate which participate in association reactions that also shift with temperature. The temperature effect on $\mathrm{pH}$ and on the association reactions of the complex anions may act to offset or magnify the effect of the increase in the $\log \mathrm{K}$ of radionuclide complexes. We can use a hypothetical simplified example to test the net effect of these changes. In this simplified example, we assume that activities are equivalent to concentrations, that is, activity coefficients are equal to one, and discount the effect of temperature in changing the free ion concentrations apart from the change created by the association reaction of interest.

For a carbonate complex reaction such as:

$$
\mathrm{UO}_{2}{ }^{2+}+2 \mathrm{HCO}_{3}{ }^{-}=\mathrm{UO}_{2}\left(\mathrm{CO}_{3}\right)_{2}{ }^{2-}+2 \mathrm{H}^{+}
$$

the concentration of the complex is given by:

$$
\left[\mathrm{UO}_{2}\left(\mathrm{CO}_{3}\right)_{2}{ }^{2-}\right]=\mathrm{K} *\left[\mathrm{UO}_{2}{ }^{2+}\right]\left[\mathrm{HCO}_{3}\right]^{2} /\left[\mathrm{H}^{+}\right]
$$

From Table 13, at $25^{\circ} \mathrm{C}, \log \mathrm{K}=-4.076$ and at $100^{\circ} \mathrm{C} \log \mathrm{K}=-2.389$. The change in temperature also affects the dissociation reaction for carbonate:

$$
\mathrm{HCO}_{3}{ }^{-}=\mathrm{H}^{+}+\mathrm{CO}_{3}{ }^{2-}
$$

The $\log \mathrm{K}$ for that reaction changes from -10.33 to -10.14 with a temperature change from 25 to $100^{\circ} \mathrm{C}$. It also affects the neutrality point for water:

$$
\mathrm{H}_{2} \mathrm{O}=\mathrm{H}^{+}+\mathrm{OH}^{-}
$$

changing the $\log \mathrm{K}$ from -14 to -12.265 , and the point of neutral $\mathrm{pH}$ from 7 to 6.1 ; if we assume a correlative shift in the $\mathrm{pH}$ for the Cheshire groundwater, a $\mathrm{pH}$ of 8.2 (typical of NTS water) shifts to 7.3. Assuming a constant concentration of $\left[\mathrm{UO}_{2}{ }^{2+}\right]$, the temperature increase to $100^{\circ} \mathrm{C}$ produces a 6-fold increase in the amount of $\mathrm{UO}_{2}\left(\mathrm{CO}_{3}\right)_{2}{ }^{2-}$ complex formed. In this case, this is a much smaller effect when compared to the 48 -fold change in the $\mathrm{K}$ for the $\mathrm{UO}_{2}\left(\mathrm{CO}_{3}\right)_{2}{ }^{2-}$ complex. While this is a greatly oversimplified example, it shows that the interdependence of the solution chemistry needs to be considered in detail before the net effect of changes in any one reaction parameter can be made reliably. 
It has been suggested that formation of colloids and sorption are two other very important processes controlling radionuclide mobility. In this context, it is important to note that many of the accepted models for sorption that include temperature dependence commonly represent sorption as complexation reactions with ions on mineral surfaces (Glynn, 2003; Missana et al., 2003; Moll et al., 1997; Waite et al., 1994; Wang et al., 2001a, b). Surface complexation modeling studies have been constrained by lack of the same thermodynamic data encountered in this study. As was done in the Cheshire HST simulations (Pawloski et al., 2001), data available at $25^{\circ} \mathrm{C}$ are typically used regardless of the temperature conditions of the model (e.g., Glynn, 2003).

By extension, if the effect of temperature is to increase aqueous complexation, it may also impact surface complexation with mineral surfaces or colloid surfaces, resulting in reduced or enhanced radionuclide mobility. Furthermore, the effectiveness of surface complexation in trapping or retarding radionuclide migration depends on the availability of mineral surfaces along the flow path and the relative rates of sorption of radionuclides and competing species. Estimating these reliably is probably a much greater source of potential error than the use of $25^{\circ} \mathrm{C}$ thermodynamic data to model complexation at higher temperatures. In addition, some reactive transport models do not conserve charge when surface complexation reactions are included. This omission introduces additional unknown error to modeling results.

Colloid formation ( $<1$ micron particles) will act to enhance radionuclide mobility by creating mobile solid particles. These particles may consist of solid radionuclide phases - mineral oxides or hydroxides, or they may be other mineral phases, such as carbonates, hydroxides or silicates, that contain radionuclides as coprecipitated or surface-sorbed trace phases. For example, low levels of $\mathrm{Pu}$ originally from the Benham underground nuclear test were detected in groundwater from two different aquifers collected from wells $1.3 \mathrm{~km}$ downgradient of the test site. Greater than $90 \%$ of the $\mathrm{Pu}$ and other radionuclides were associated with naturally occurring colloids in the groundwater. The colloids consisted mainly of clays (illite, smectite), zeolite (mordenite, clinoptilolite/heulandite), and cristobalite $\left(\mathrm{SiO}_{2}\right)$ (Kersting et al., 1999; Kersting and Reimus, 2003). The potential for colloids to transport radionuclides is affected by numerous criteria (e.g., Ryan and Elimelech, 1996; Stumm and Morgan, 1981):

1) colloids must exist and be stable (not agglomerate or settle out of suspension),

2) radionuclides must have a high sorption affinity for the colloids,

3) colloids must be transported by the groundwater,

4) degree of irreversibility of sorption onto colloids,

5) formation potential for intrinsic radionuclide colloids.

Because of this complex scenario, it is difficult to determine the direction of the impact of temperature increase on colloidal formation or transport. The stability of colloids, for example, partly depends on rates of collisions and settling, and both of these processes are temperaturedependent. The precipitation potentials or saturation states of specific radionuclide solid phases, of other colloid-forming minerals, and the stabilities of sorbed radionuclide surface complexes also depend on temperature. Modeling these processes is constrained by lack of some of the same thermodynamic data that limits the ability to extrapolate aqueous complexation to higher temperatures. 


\section{CONCLUSIONS AND RECOMMENDATIONS}

In the absence of more thermodynamic data and/or algorithms tested for pentavalent and hexavalent cations, and for the types of anionic complexes pertinent to the conditions at Cheshire, and in consideration of the magnitude of errors produced by this approach relative to errors from omission of other processes in current models (e.g., colloidal sorption), use of $25^{\circ} \mathrm{C}$ $\log \mathrm{K}$ values appears to be the best available option for modeling radionuclide aqueous speciation for Cheshire. For some reactions involving tetravalent and trivalent cations, the Shock-Helgeson algorithm appears to give reliable estimates for heat capacities. For complexation reactions that could be written as isocoulombic reactions, if enthalpy data are available for all species, $\log \mathrm{K}$ values at higher temperatures can be calculated assuming heat capacities of reaction are zero. For these few reactions where extrapolations can be made with confidence, it appears that the changes in $\mathrm{K}$ with temperature are only large (orders of magnitude over the temperature range from 0 to $300^{\circ} \mathrm{C}$ ) for a few of them, those characterized by high enthalpies of reaction. However, it is also important to note that any mobility increase from increased aqueous complexation caused by an increase in temperature may be decreased by concurrent increased surface complexation of radionuclides on mineral surfaces, but conversely may be increased by enhanced surface sorption onto mobile colloids.

Complexation reactions often involve $\mathrm{H}^{+}$and reactant species such as carbonate which exhibit their own temperature-dependent speciation. Thus, an increasing radionuclide complexation log $\mathrm{K}$ may be enhanced or diminished by temperature effects on $\mathrm{pH}$ and carbonate speciation. In addition, sorption processes that involve surface complexation may also change with increasing temperature, and these reactions might enhance or negate the mobility effects of any increase in aqueous complexation with temperature. While increasing temperature may increase complexation, it also may reduce or increase ligand concentrations through shifts in speciation. Similarly, higher temperatures may favor or reduce sorption and/or co-precipitation in mineral phases. Consequently, the net effect on radionuclide mobility of increasing temperature depends on the effects of temperature on a number of geochemical processes. Thus, it is difficult to make even qualitative assumptions about the direction much less the magnitude of temperature effects on radionuclide mobility. Until sufficient data become available in the literature to precisely capture the effects of temperature on radionuclide complexation, it appears unwarranted to invest in complex estimation techniques based on extrapolations from the few available data. Any future work to obtain the necessary thermodynamic data to constrain the temperature effect should focus on reactions involving species and complexes that are likely to be characterized by high enthalpies. For Cheshire, carbonate complexes are likely to be the most important.

In the context of field-scale transport modeling, it is also apparent that using $25^{\circ} \mathrm{C}$ complexation data for all temperatures is presently the best transport modeling alternative for the Cheshire HST. The model error associated with using $25^{\circ} \mathrm{C}$ complexation constants is likely small relative to many other assumptions made in the modeling. High temperatures are located primarily in the glass zone of underground nuclear tests. The volume of the glass zone is very small when compared to the region encompassed by the 1000-year transport path of most radionuclides. Furthermore, high temperatures in the glass zone are transient and are not likely to be present over the entire 1000-year HST modeling timeframe. Thus, spatially and temporally within the 
models, the overall effect of neglecting complexation temperature dependence on the results of long-term and long-distance reactive transport modeling will be small. However, this is not to imply that temperature gradients are unimportant over the far-field region or over long-time frames. Temperature gradients will control radionuclide transport through many physical as well as chemical effects, including thermal buoyancy effects, convection, solubility and species concentration gradients, all of which will impact the thermodynamic drive and kinetics of complex formation, sorption, colloidal transport, ion exchange and many other reactions. Given the nonlinearity of the system, it remains difficult to predict either the magnitude or direction of the impact of neglecting temperature effects on $\log \mathrm{K}$ values on the source term, release rates, and long-term and long-range mobility.

\section{ACKNOWLEDGMENTS}

Funding for this investigation was provided by the Environment Restoration Division's Underground Test Area Project at the U.S. Department of Energy, National Nuclear Security Administration, Nevada Site Office. This work was performed under the auspices of the U.S. Department of Energy by Lawrence Livermore National Laboratory under contract number W7405-Eng-48. 


\section{REFERENCES}

Anderson, G. M., Castet, S., Schott, J., and Mesmer, R. E., 1991, The density model for estimation of thermodynamic parameters of reactions at high temperatures and pressures: Geochimica et Cosmochimica Acta, v. 55, p. 1769-1779.

Anderson, G. M., and Crerar, D. A., 1993, Thermodynamics in Geochemistry: New York, Oxford University Press, 588 p. p.

Carle S. F., Maxwell R. M., and Pawloski G. A. (2003) Impact of Test Heat on Groundwater Flow at Pahute Mesa, Nevada Test Site. Livermore, California, Lawrence Livermore National Laboratory, UCRL-ID-152599.

Choppin, G. R., and Rizkalla, E. N., 1994, Solution chemistry of actinides and lanthanides, Ch.128, in Gschneidner Jr., K. A., Eyring, L., Choppin, G., and R., L., G. H.,, eds., Handbook on the physics and chemistry of rare earths,: Amsterdam, Elsevier Science, p. 559-590.

Criss, C. M., and Cobble, J. W., 1964a, The thermodynamic properties of high temperature aqueous solutions. IV. Entropies of the ions up to 200o and the Correspondence Principle: Journal of the American Chemical Society, v. 86, p. 5385-5390.

Criss, C. M., and Cobble, J. W., 1964b, The thermodynamic properties of high temperature aqueous solutions. V. The calculation of ionic heat capacities up to $200 \mathrm{oC}$. Entropies and heat capacities above 200o: Journal of the American Chemical Society, v. 86, p. 53905393.

Glynn, P. D., 2003, Modeling Np and Pu transport with a surface complexation model and spatially variant sorption capacities: implications for reactive transport modeling and performance assessments of nuclear waste disposal sites: Computers \& Geosciences, v. 29, p. 331-349.

Grenthe, I., Fuger, J., Konings, R. J. M., Lemire, R. J., Muller, A. B., Nguyen-Trung, C., and Wanner, H., 1992, Chemical Thermodynamics of Uranium, Chemical Thermodynamics: Amsterdam, North-Holland, $715 \mathrm{p}$.

Guillaumont, R., Fanghanel, T., Fuger, J., Grenthe, I., Neck, V., Palmer, D. A., and Rand, M. H., 2003, Update on the Chemical Thermodynamics of Uranium, Neptunium, Plutonium, Americium and Technetium, Chemical Thermodynamics: Amsterdam, Elsevier, 918 p.

Helgeson, H.C., Kirkham, D.H. and Flowers, G.C., 1981, Theoretical prediction of the thermodynamic behavior of aqueous electrolytes at high pressure and temperatures. IV. Calculation of activity coefficients, osmotic coefficients, and apparent molal and standard and relative partial molal properties to $5 \mathrm{~kb}$ and $600^{\circ}$ C. Am. J. Sci., v. 281, p. 1241-1516.

Hovey, J. K., 1997, Thermodynamics of hydration of a 4+ aqueous ion: partial molar heat capacities and volumes of aqueous thorium(IV) from 10 to $55 \mathrm{oC}$, J. Phys. Chem. B, v. 101, p. 4321-4334.

Kasuba, J.P. and Runde, W.H., 1999, The aqueous geochemistry of Neptunium: Dynamic control of soluble concentrations with applications to nuclear waste disposal. Environmental Science and Technology, v. 33, p. 4427-4433.

Kersting, A. B., Efurd, D. W., Finnegan, D. L., Rokop, D. J., Smith, D. K., and Thompson, J. L., 1999, Migration of Plutonium in Groundwater at the Nevada Test Site: Nature, v. 397, p. 56-59. 
Kersting, A. B., and Reimus, P. W. E., 2003, Colloid-facilitated transport of low-solubility radionuclides: a field, experimental, and modeling investigation: Lawrence Livermore National Laboratory, UCRL-ID-149688.

Lemire, R.J., and Tremaine, R.M., 1980, Uranium and plutonium equilibria in aqueous solutions to $200^{\circ}$ C. J. Chem. Eng. Data, v. 25, p. 361-370.

Lemire, R. J., Fuger, J., Nitsche, H., Potter, P., Rand, M. H., Rydber, J., Spahiu, K., Sullivan, J. C., Ullman, W. J., Vitorge, P., and Wanner, H., 2001, Chemical Thermodynamics of Neptunium and Plutonium, Chemical Thermodynamics: Amsterdam, North-Holland, 845 p.

Mesmer, R. E., Marshall, W. L., Palmer, D. A., Simonson, J. M., and Holmes, H. F., 1988, Thermodynamics of aqueous association and ionization reactions at high temperatures and pressures: Journal of Solution Chemistry, v. 17, no. 8, p. 699-718.

Missana, T., Garcia-Gutierrez, M., and Fernandez, V., 2003, Uranium (VI) sorption on colloidal magnetite under anoxic environment: Experimental study and surface complexation modeling: Geochimica et Cosmochimica Acta, v. 67, no. 14, p. 2543-2550.

Moll, H., Brachmann, A., Wruck, D. A., and Palmer, C. E. A., 1997, Status of solubility data for selected elements (U, Np, Pu, Am, Tc, Ni, and Zr): Lawrence Livermore National Laboratory, UCRL-ID-128956, 26 p.

Morss, L. R. and McCue, M. C., 1976, Partial molal entropy and heat capacity of the aqueous thorium(IV) ion. Thermochemistry of thorium nitrate pentahydrate: J. Chem. Eng. Data, v. 21, p. 337-341.

Neck, V., and Kim, J. I., 2001, Solubility and hydrolysis of tetravalent actinides,: Radiochimica Acta, v. 89, p. 1-16.

Nuclear Energy Agency, Thermodynamic Database Project. http://www.nea.fr/html/dbtdb/).

Pawloski G. A., Tompson A. F. B., and Carle S. F. (2001) Evaluation of the Hydrologic Source Term from Underground Nuclear Tests on Pahute Mesa at the Nevada Test Site: The CHESHIRE Test, Bourcier, W.L., Bruton, C.J., Carle, S.F., Daniels, J.I., Maxwell, R.M., Pawloski, G.A., Shumaker, D.S., Smith, D.K., Tompson, A.F.B., and Zavarin, M., Contributors. Livermore, California, Lawrence Livermore National Laboratory, UCRLID-147023.

Puigdomenech, I., Rard, J. A., Plyasunov, A. V., and Grenthe, I., 1997, Temperature Corrections to Thermodynamic Data and Enthalpy Calculations, Thermodynamic Modeling of Aqueous Systems.

Ryan, J. N., and Elimelech, M., 1996, Colloid mobilization and transport in groundwater: Colloids and Surfaces A: Physiochemical and Engineering Aspects, v. 107, p. 1-56.

Shock, E. L., and Helgeson, H. C., 1988, Calculation of the thermodynamic and transport properties of aqueous species at high pressures and temperatures: Correlation algorithms for ionic species and equation of state predictions to $5 \mathrm{~kb}$ and $1000 \mathrm{C}$ : Geochimica et Cosmochimica Acta, v. 52, p. 2009-2036.

Shock, E. L., Oelkers, E. H., Johnson, J. W., Sverjensky, D. A., and Helgeson, H. C., 1992, Calculation of the thermodynamic properties of aqueous species at high pressures and temperatures: Journal of the Chemical Society Faraday Transactions, v. 88, no. 6, p. 803826.

Shock, E. L., Sassani, D. C., and Betz, H., 1997a, Uranium in geologic fluids: estimates of standard partial molal properties, oxidation potentials, and hydrolysis constants at high 
temperature and pressure: Geochimica et Cosmochimica Acta, v. 61, no. 20, p. 42454266.

Shock, E. L., Sassani, D. C., Willis, M., and Sverjensky, D. A., 1997b, Inorganic species in geologic fluids: Correlations among standard molal thermodynamic properties of aqueous ions and hydroxide complexes: Geochimica et Cosmochimica Acta, v. 61, no. 5, p. $907-$ 950.

Silva, R. J., Bidoglio, G., Rand, M. H., Robouch, P., Wanner, H., Puigdomènech, I., 1995, Chemical Thermodynamics of Americium: Chemical Thermodynamics vol. 2, Nuclear Energy Agency, Organisation for Economic Cooperation, Development, Ed., North Holland Elsevier Science Publishers B. V., Amsterdam, The Netherlands, (1995), 374 pp.

Stumm, W., and Morgan, J. J., 1981, Aquatic Chemistry: New York, Wiley-Interscience, 780 p. Waite, T. D., Davis, J. A., Payne, T. E., Waychunas, G. A., and Xu, N., 1994, Uranium (VI) adsorption to ferrihydrite: application of a surface complexation model: Geochimica et Cosmochimica Acta, v. 58, no. 24, p. 5465-5478.

Wang, P., Anderko, A., and Turner, D. R., 2001a, Thermodynamic Modeling of the Adsorption of Radionuclides on Selected Minerals. I: Cations: American Chemical Geology, v. Ind. Eng., Chem. Res., no. 40, p. 4428-4443.

Wang, P., Anderko, A., and Turner, D. R., 2001b, Thermodynamic Modeling of the Adsorption of Radionuclides on Selected Minerals. II: Anions: American Chemical Geology, v. Ind. Eng., Chem. Res., no. 40, p. 4444-4455.

Wolery, T., 1983, EQ3NR, A computer program for geochemical aqueous speciation-solubility calculations: Users guide and documentation, Lawrence Livermore National Laboratory, Livermore, CA, UCRL-53414, $191 \mathrm{p}$.

Wolfsberg, A., Glascoe, L., Lu, G., Olson, A., Lichtner, P., McGraw, M., Cherry, T., Roemer, G., 2002, TYBO/BENHAM: Model Analysis of Groundwater Flow and Radionuclide Migration from Underground Nuclear Tests in Southwestern Pahute Mesa, Nevada: LA13977-MS, Los Alamos National Laboratory, Los Alamos, NM.

Wruck, D. A., and Palmer, C. E. A., 1997, Analysis of elevated temperature data for thermodynamic properties of selected radionuclides: Lawrence Livermore National Laboratory. UCRL-ID-128955. 19 p.

Wruck, D. A., Palmer, C. E. A., and Silva, R. J., 1999, A study of Americium (III) carbonate complexation at elevated temperatures by pulsed laser photoacoustic spectroscopy: Radiochimica Acta, v. 85, p. 21-24. 


\section{APPENDIX : SELECTED REFERENCES FROM LITERATURE SEARCH}

Amme, M., 2002, Geochemical Modelling as a Tool for Actinide Speciation during Anoxic Leaching Processes of Nuclear Fuel: Aquatic Geochemistry, v. 8, p. 177-198.

Anderson, G. M., Castet, S., Schott, J., and Mesmer, R. E., 1991, The density model for estimation of thermodynamic parameters of reactions at high temperatures and pressures: Geochimica et Cosmochimica Acta, v. 55, p. 1769-1779.

Anderson, G. M., and Crerar, D. A., 1993, Thermodynamics in Geochemistry: New York, Oxford University Press, 588 p.

Baes, C. F., Jr., and Mesmer, R. E., 1981, The thermodynamics of cation hydrolysis: American Journal of Science, v. 281, p. 935-962.

Belveze, L. S., Brennecke, J. F., and Stadtherr, M. A., 2004, Modeling of Activity Coefficients of Aqueous Solutions of Quaternary Ammonium Salts with the Electrolyte-NRTL Equation: American Chemical Society, v. Ind. Chem. Res., no. 43, p. 815-825.

Bidoglio, G., Avagadro, A., Plano, A. D., and Lazzari, G. P., 1988, Reaction pathways of Pu and $\mathrm{Np}$ in selected natural water environments: Radiochimica Acta, v. 44-45, p. 29-32.

Brand, J. R., and Cobble, J. W., 1970, The thermodynamic functions of neptunium (V) and neptunium (VI): Inorganic Chemistry, v. 9, p. 912-917.

Bruno, J., Duro, L., and Grive, M., 2002, The applicability and limitations of thermodynamic geochemical models to simulate trace element behaviour in natural waters. Lessons learned from natural analogue studies: Chemical Geology, v. 190, p. 371-393.

Bryzgalin, O. V., 1986, Estimating dissociation constants in the supercritical region for some strong electrolytes from an electrostatic model: Geochemistry International, v. 23, no. 2, p. 8495.

Bryzgalin, O. V., 1995, Estimating activity coefficients of some electrolyte groups over wide ranges in P, T, and concentration: Geochemistry International, v. 32, no. 1, p. 71-85.

Buffle, J., Tercier, M. L., Parthasarathy, N., and Wilkinson, K. J., 1997, Analytical techniques for the in situ measurement and speciation of trace compounds in natural waters: Chimia, v. 51, no. 10 , p. $690-693$.

Choppin, G. R., Bond, A. H., and Hromadka, P. M., 1997, Redox speciation of plutonium: Journal of Radioanalytical and Nuclear Chemistry, v. 219, no. 2, p. 203-210.

Choppin, G. R., and Rizkalla, E. N., 1994, Solution chemistry of actinides and lanthanides, Ch.128, in Gschneidner Jr., K. A., Eyring, L., Choppin, G., and R., L., G. H.,, eds., Handbook on the physics and chemistry of rare earths,: Amsterdam, Elsevier Science, p. 559-590. 
Choppin, G. R., and Wong, P. J., 1998, The Chemistry of Actinide Behavior in Marine Systems: Aquatic Geochemistry, v. 4, p. 77-101.

Cooper, E. L., Haas, M. K., and Mattie, J. F., 1995, Studies of the Speciation of Plutonium and other Actinides in Natural Groundwater Using Anion Exchange Resin: Applied Radiat. Isot., v. 46, no. 11, p. 1159-1173.

Criss, C. M., and Cobble, J. W., 1964, The thermodynamic properties of high temperature aqueous solutions. IV. Entropies of the ions up to $200 \mathrm{o}$ and the Correspondence Principle: Journal of the American Chemical Society, v. 86, p. 5385-5390.

Criss, C. M., and Cobble, J. W., 1964, The thermodynamic properties of high temperature aqueous solutions. V. The calculation of ionic heat capacities up to $200 \mathrm{oC}$. Entropies and heat capacities above 200o: Journal of the American Chemical Society, v. 86, p. 5390-5393.

Criss, C. M., and Millero, F. J., 1999, Modeling Heat Capacities of High Valence-Type Electrolyte Solutions with Pitzer Equations: Journal of Solution Chemistry, v. 28, no. 7, p. 849.

David, F., 1986, Thermodynamic properties of the lanthanide and actinide ions in aqueous solution: Journal of the Less-Common Metals, v. 121, p. 27-42.

El-Naggar, H. A., Ezz El-Din, M. R., and Sheha, R. R., 2000, Speciation of neptunium migration in under groundwater: Journal of Radioanalytical and Nuclear Chemistry, v. 246, no. 3, p. 493504.

Fanghanel, T., and Kim, J. I., 1998, Spectroscopic evaluation of thermodynamics of trivalent actinides in brines: Journal of Alloys and Compounds, v. 271 273, p. 728-737.

Filella, M., and May, P. M., 2003, Computer simulation of the low-molecular-weight inorganic species distribution of antimony (III) and antimony (V) in natural waters: Geochimica et Cosmochimica Acta, v. 67, no. 21, p. 4013-4031.

Glynn, P. D., 2003, Modeling Np and Pu transport with a surface complexation model and spatially variant sorption capacities: implications for reactive transport modeling and performance assessments of nuclear waste disposal sites: Computers \& Geosciences, v. 29, p. 331-349.

Grenthe, I., Fuger, J., Konings, R. J. M., Lemire, R. J., Muller, A. B., Nguyen-Trung, C., and Wanner, H., 1992, Chemical Thermodynamics of Uranium, Chemical Thermodynamics: Amsterdam, North-Holland, $715 \mathrm{p}$.

Guillaumont, R., Fanghanel, T., Fuger, J., Grenthe, I., Neck, V., Palmer, D. A., and Rand, M. H., 2003, Update on the Chemical Thermodynamics of Uranium, Neptunium, Plutonium, Americium and Technetium, Chemical Thermodynamics: Amsterdam, Elsevier, 918 p. 
Helgeson, H. C., 1967, Thermodynamics of complex dissociation in aqueous solution at elevated temperatures: Journal of Physical Chemistry, v. 71, p. 3121-3136.

Helgeson, H. C., and Kirkham, D. H., 1974, Theoretical prediction of the thermodynamic behavior of aqueous electrolytes at high pressures and temperatures: I. Summary of the thermodynamic/ electrostatic properties of the solvent: American Journal of Science, v. 274, p. 1089-1198.

Helgeson, H. C., and Kirkham, D. H., 1974, Theoretical prediction of the thermodynamic behavior of aqueous electrolytes at high pressures and temperatures: II. Debye-Huckel parameters for activity coefficients and relative partial molal properties: American Journal of Science, v. 274, p. 1199-1261.

Helgeson, H.C., Kirkham, D.H. and Flowers, G.C., 1981, Theoretical prediction of the thermodynamic behavior of aqueous electrolytes at high pressure and temperatures. IV. Calculation of activity coefficients, osmotic coefficients, and apparent molal and standard and relative partial molal properties to $5 \mathrm{~kb}$ and $600^{\circ} \mathrm{C}$. Am. J. Sci., v. 281, p. 1241-1516.

Hinchey, R. J., and Cobble, J. W., 1970, Standard-state entropies for the aqueous trivalent lanthanide and yttrium ions: Inorganic Chemistry, v. 9, p. 917-921.

Hinchey, R. J., and Cobble, J. W., 1970, The thermodynamic functions for Pu3+(aq) and the entropies for some trivalent actinide ions: Inorganic Chemistry, v. 9, p. 922-926.

Hovey, J. K., 1997, Thermodynamics of hydration of a 4+ aqueous ion: partial molar heat capacities and volumes of aqueous thorium(IV) from 10 to 55oC: J. Phys. Chem. B, v. 101, p. 4321-4334.

Johannesson, K. H., Stetzenbach, K. J., and Hodge, V. F., 1995, Speciation of the rare earth element neodymium in groundwaters of the Nevada Test Site and Yucca Mountain and implications for actinide solubility: Applied Geochemistry, v. 10, p. 565-572.

Johansson, B., 2000, Structural and electronic relationships between the lanthanide and actinide elements: Hyperfine Interactions, v. 128, p. 41-66.

Kakiuchi, H., Amano, H., and Ichimasa, M., 2002, Chemical speciation of radionuclides through the microbial process in soils: Journal of Radioanalytical and Nuclear Chemistry, v. 252, no. 2, p. 437-439.

Kasuba, J.P. and Runde, W.H., 1999, The aqueous geochemistry of Neptunium: Dynamic control of soluble concentrations with applications to nuclear waste disposal. Environmental Science and Technology, v. 33, p. 4427-4433. 
Khodakovskiy, I. L., 1969, Thermodynamics of aqueous solutions of electrolytes at elevated temperatures (entropies of ions in aqueous solutions at elevated temperatures): Geochemistry International, v. 6, p. 29-34.

Konings, R. J. M., 2004, The heat capacity and entropy of actinides(IV) compounds: Journal of Chemical Thermodynamics, v. 36, p. 121-126.

Lemire, R. J., Fuger, J., Nitsche, H., Potter, P., Rand, M. H., Rydber, J., Spahiu, K., Sullivan, J. C., Ullman, W. J., Vitorge, P., and Wanner, H., 2001, Chemical Thermodynamics of Neptunium and Plutonium, Chemical Thermodynamics: Amsterdam, North-Holland, $845 \mathrm{p}$.

Lemire, R. J., and Tremaine, P. R., 1980, Uranium and plutonium equilibria in aqueous solutions to 200 C: Journal of Chemical and Engineering Data, v. 25, p. 361-370.

Li, B., and Byrne, R. H., 1997, Ionic Strength Dependence of Rare Earth NTA Stability Constants at 25 degree C: Aquatic Geochemistry, v. 3, p. 99-115.

Liu, C. X., Zachara, J. M., Qafoku, O., and Smith, S. C., 2003, Effect of Temperature on Cs+ Sorption and Desorption in Subsurface Sediments at the Hanford Site, U. S. A.: Environmental Science \& Technology, v. 12, no. 37, p. 2640-2645.

Luo, Y.-R., and Byrne, R. H., 2001, Yttrium and Rare Earth Element Complexation by Chloride Ions at 25 degree C: Journal of Solution Chemistry, v. 30, p. 837.

May, P. M., and Murray, K., 1991, Jess, A Joint Expert Speciation System-I. Raison D'Etre: Talanta, v. 38, no. 12, p. 1409-1417.

May, P. M., and Murray, K., 1991, Jess, A Joint Expert Speciation System-II. The Thermodynamic Database: Talanta, v. 38, no. 12, p. 1419-1426.

May, P. M., and Murray, K., 1991, Jess, A Joint Expert Speciation System-III. Surrogate Functions: Talanta, v. 40, no. 6, p. 819-825.

Menard, O., Advocat, T., Ambrosi, J. P., and Michard, A., 1998, Behaviour of actinides (Th, U, $\mathrm{Np}$ and $\mathrm{Pu}$ ) and rare earths ( $\mathrm{La}, \mathrm{Ce}$ and $\mathrm{Nd}$ ) during aqueous leaching of a nuclear glass under geological disposal conditions: Applied Geochemistry, v. 13, p. 105-126.

Mesmer, R. E., Marshall, W. L., Palmer, D. A., Simonson, J. M., and Holmes, H. F., 1988, Thermodynamics of aqueous association and ionization reactions at high temperatures and pressures: Journal of Solution Chemistry, v. 17, no. 8, p. 699-718.

Missana, T., Garcia-Gutierrez, M., and Fernnndez, V., 2003, Uranium (VI) sorption on colloidal magnetite under anoxic environment: Experimental study and surface complexation modeling: Geochimica et Cosmochimica Acta, v. 67, no. 14, p. 2543-2550. 
Moll, H., Brachmann, A., Wruck, D. A., and Palmer, C. E. A., 1997, Status of solubility data for selected elements (U, Np, Pu, Am, Tc, Ni, and Zr): Lawrence Livermore National Laboratory, UCRL-ID-128956, 26 p.

Morss, L. R., 1986, Thermodynamic Properties, in Katz, J., Seaborg, G.T. and Morss, L.R., ed., The chemistry of the actinide elements: London, Chapman and Hall, p. 1278-1360.

Morss, L. R. and McCue, M. C., 1976, Partial molal entropy and heat capacity of the aqueous thorium(IV) ion. Thermochemistry of thorium nitrate pentahydrate: J. Chem. Eng. Data, v. 21, p. 337-341.

Neck, V., and Kim, J. I., 2001, Solubility and hydrolysis of tetravalent actinides: Radiochimica Acta, v. 89, p. 1-16.

Nelson, D. M., Orlandini, K. A., and Penrose, W. R., 1989, Oxidation states of plutonium in carbonate-rich natural waters: Journal of Environmental Radioactivity, v. 9, p. 189-198.

Nicholson, K. N., and Wood, S. A., 2002, Aqueous Geochemistry for Rare Earth Elements and Yttrium. XII: Potentiometric Stability Constant Determination of Bis-Tris Complexes with La, $\mathrm{Nd}, \mathrm{Eu}, \mathrm{Gd}, \mathrm{Yb}, \mathrm{Dy}, \mathrm{Er}, \mathrm{Lu}$, and Y: Journal of Solution Chemistry, v. 31, no. 9, p. 703.

Nuclear Energy Agency, Thermodynamic Database Project. http://www.nea.fr/html/dbtdb/).

Phillips, S. L., and Silvester, L. F., 1984, A data base for nuclear waste disposal for temperatures up to 300 C: High Temperatures - High Pressures, v. 16, p. 81-91.

Puigdomenech, I., Rard, J. A., Plyasunov, A. V., and Grenthe, I., 1997, Temperature Corrections to Thermodynamic Data and Enthalpy Calculations, Thermodynamic Modelling of Aqueous Systems.

Ragnarsdottir, K. V., Fournier, P., Oelkers, E. H., and Harrichoury, J.-C., 2001, Experimental determination of the complexation of strontium and cesium with acetate in high-temperature aqueous solutions: Geochimica et Cosmochimica Acta, v. 65, no. 21, p. 3955-3964.

Rai, D., Felmy, A. R., and Yui, M., 2003, Thermodynamic model for the solubility of NdPO4(c) in the aqueous NA+-H+-H2PO4--HPO42-OH--CI-H20 System: Journal of Radioanalytical and Nuclear Chemistry, v. 256, no. 1, p. 37-43.

Sahai, N., 2000, Estimating adsorption enthalpies and affinity sequences of monovalent electrolyte ions on oxide surfaces in aqueous solution: Geochimica et Cosmochimica Acta, v. 64, no. 21 , p. 3629-3641.

Sergeyeva, E. I., Nikitin, A. A., Khodakovskiy, I. L., and Naumov, G. B., 1972, Experimental investigation of equilibria in the system $\mathrm{UO}_{3}-\mathrm{CO}_{2}-\mathrm{H}_{2} \mathrm{O}$ in $25-200 \mathrm{C}$ temperature interval: Geochemistry International, v. 9, p. 900-910. 
Shock, E. L., and Helgeson, H. C., 1988, Calculation of the thermodynamic and transport properties of aqueous species at high pressures and temperatures: Correlation algorithms for ionic species and equation of state predictions to $5 \mathrm{~kb}$ and $1000 \mathrm{C}$ : Geochimica et Cosmochimica Acta, v. 52, p. 2009-2036.

Shock, E. L., Oelkers, E. H., Johnson, J. W., Sverjensky, D. A., and Helgeson, H. C., 1992, Calculation of the thermodynamic properties of aqueous species at high pressures and temperatures: Journal of the Chemical Society Faraday Transactions, v. 88, no. 6, p. 803-826.

Shock, E. L., Sassani, D. C., and Betz, H., 1997, Uranium in geologic fluids: estimates of standard partial molal properties, oxidation potentials, and hydrolysis constants at high temperature and pressure: Geochimica et Cosmochimica Acta, v. 61, no. 20, p. 4245-4266.

Shock, E. L., Sassani, D. C., Willis, M., and Sverjensky, D. A., 1997, Inorganic species in geologic fluids: Correlations among standard molal thermodynamic properties of aqueous ions and hydroxide complexes: Geochimica et Cosmochimica Acta, v. 61, no. 5, p. 907-950.

Silva, R. J., Bidoglio, G., Rand, M. H., Robouch, P., Wanner, H., Puigdomènech, I., 1995, Chemical Thermodynamics of Americium: Chemical Thermodynamics vol. 2, Nuclear Energy Agency, Organisation for Economic Cooperation, Development, Ed., North Holland Elsevier Science Publishers B. V., Amsterdam, The Netherlands, 374 pp.

Stout, B. E., Choppin, G. R., and Sullivan, J. C., 1992, The chemistry of uranium (VI), neptunium (VI) and plutonium (VI) in aqueous carbonate solutions, in Morss, L. R., ed., Transuranium Elements: A half-century: Washington, D.C., American Chemical Society.

Stumm, W., and Morgan, J. J., 1981, Aquatic Chemistry: New York, Wiley-Interscience, 780 p.

Tanger, J. C., IV, and Helgeson, H. C., 1988, Calculation of the thermodynamic and transport properties of aqueous species at high pressures and temperatures: Revised equations of state for the standard partial molal properties of ions and electrolytes: American Journal of Science, v. 288, p. 19-98.

Waite, T. D., Davis, J. A., Payne, T. E., Waychunas, G. A., and Xu, N., 1994, Uranium (VI) adsorption to ferrihydrite: application of a surface complexation model: Geochimica et Cosmochimica Acta, v. 58, no. 24, p. 5465-5478.

Wang, P., Anderko, A., and Turner, D. R., 2001, Thermodynamic Modeling of the Adsorption of Radionuclides on Selected Minerals. I: Cations: American Chemical Geology, v. Ind. Eng., Chem. Res., no. 40, p. 4428-4443.

Wang, P., Anderko, A., and Turner, D. R., 2001, Thermodynamic Modeling of the Adsorption of Radionuclides on Selected Minerals. II: Anions: American Chemical Geology, v. Ind. Eng., Chem. Res., no. 40, p. 4444-4455. 
Webb, L. M., Taylor, D. M., and Williams, D. R., 1998, Computer modelling of the chemical speciation of lanthanide and actinide elements in the human gastrointestinal tract: Journal of Alloys and Compounds, v. 271-273, p. 112-115.

Wolery, T., 1983, EQ3NR, A computer program for geochemical aqueous speciation-solubility calculations: Users guide and documentation. Lawrence Livermore National Laboratory, Livermore, CA, UCRL-53414, 191 p.

Wolfsberg, A., Glascoe, L., Lu, G., Olson, A., Lichtner, P., McGraw, M., Cherry, T., Roemer, G., 2002, TYBO/BENHAM: Model Analysis of Groundwater Flow and Radionuclide Migration from Underground Nuclear Tests in Southwestern Pahute Mesa, Nevada: LA-13977-MS, Los Alamos National Laboratory, Los Alamos, NM.

Wruck, D. A., and Palmer, C. E. A., 1997, Analysis of elevated temperature data for thermodynamic properties of selected radionuclides: Lawrence Livermore National Laboratory. UCRL-ID-128955. 19 p.

Wruck, D. A., Palmer, C. E. A., and Silva, R. J., 1999, A study of Americium (III) carbonate complexation at elevated temperatures by pulsed laser photoacoustic spectroscopy:

Radiochimica Acta, v. 85, p. 21-24.

Xia, Y., Rao, L., Rai, D., and Felmy, A. R., 2001, Determining the distribution of Pu, Np, and U oxidation states in dilute $\mathrm{NaC} 1$ and synthetic brine solutions: Journal of Radioanalytical and Nuclear Chemistry, v. 250, no. 1, p. 27-37.

Yeh, M., Maddison, A. P., and Clark, S. B., 2000, Temperature dependence of chloride complexation for the trivalent f-elements: Journal of Radioanalytical and Nuclear Chemistry, v. 243, no. 3, p. 645-650. 